\title{
Catalytic Cycle of Multicopper Oxidases Studied by Combined Quantum- and Molecular-Mechanical Free-Energy Perturbation Methods
}

Jilai Li, Maryam Farrokhnia, Lubomir Rulisek, and Ulf Ryde

J. Phys. Chem. B, Just Accepted Manuscript • Publication Date (Web): 03 Jun 2015

Downloaded from http://pubs.acs.org on June 4, 2015

\section{Just Accepted}

"Just Accepted" manuscripts have been peer-reviewed and accepted for publication. They are posted online prior to technical editing, formatting for publication and author proofing. The American Chemical Society provides "Just Accepted" as a free service to the research community to expedite the dissemination of scientific material as soon as possible after acceptance. "Just Accepted" manuscripts appear in full in PDF format accompanied by an HTML abstract. "Just Accepted" manuscripts have been fully peer reviewed, but should not be considered the official version of record. They are accessible to all readers and citable by the Digital Object Identifier (DOI®). "Just Accepted" is an optional service offered to authors. Therefore, the "Just Accepted" Web site may not include all articles that will be published in the journal. After a manuscript is technically edited and formatted, it will be removed from the "Just Accepted" Web site and published as an ASAP article. Note that technical editing may introduce minor changes to the manuscript text and/or graphics which could affect content, and all legal disclaimers and ethical guidelines that apply to the journal pertain. ACS cannot be held responsible for errors or consequences arising from the use of information contained in these "Just Accepted" manuscripts. 


\title{
Catalytic Cycle of Multicopper Oxidases Studied by Combined Quantum- and Molecular-Mechanical Free-Energy Perturbation Methods
}

\author{
Jilai Li, ${ }^{a, b}$ Maryam Farrokhnia, ${ }^{a, c}$ Lubomír Rulíšek, ${ }^{d}$ Ulf Ryde ${ }^{a *}$ \\ a Department of Theoretical Chemistry, Lund University, Chemical Centre, P. O. Box 124, \\ SE-221 00 Lund, Sweden \\ ${ }^{b}$ Institute of Theoretical Chemistry, Jilin University, Changchun 130023, People's \\ Republic of China \\ ${ }^{c}$ The Persian Gulf marine biotechnology research center, The Persian Gulf biomedical \\ sciences research institute, University of Medical Sciences, Bushehr, Iran. \\ d Institute of Organic Chemistry and Biochemistry, Gilead Sciences \& IOCB Research \\ Center, Academy of Sciences of the Czech Republic, Flemingovo náměstí 2, 16610 \\ Prague 6, Czech Republic
}

Correspondence to Ulf Ryde, E-mail: Ulf.Ryde@teokem.lu.se,

Tel: $+46-46$ 2224502, Fax: $+46-462228648$

2015-05-07 


\begin{abstract}
We have used combined quantum mechanical and molecular mechanical free-energy perturbation methods in combination with explicit solvent simulations to study the reaction mechanism of the multicopper oxidases, in particular the regeneration of the reduced state from the native intermediate. For 52 putative states of the trinuclear copper cluster, differing in the oxidation states of the copper ions and the protonation states of water- and O2-derived ligands, we have studied redox potentials, acidity constants, isomerisation reactions, as well as water- and $\mathrm{O} 2$ binding reactions. Thereby, we can propose a full reaction mechanism of the multicopper oxidases with atomic detail. We also show that the two copper sites in the protein communicate so that redox potentials and acidity constants of one site are affected by up to $0.2 \mathrm{~V}$ or $3 p K_{a}$ units by a change in the oxidation state of the other site.
\end{abstract}

Keywords: multicopper oxidases, $\mathrm{CueO}$, redox potential, acidity constant, quantum-mechanical calculations, free-energy perturbation, QM/MM 


\section{Introduction}

The multicopper oxidases (MCOs) are a group enzymes that couple the oxidation of various substrates with the reduction of $\mathrm{O}_{2}:{ }^{1}$

$$
\mathrm{O}_{2}+4 \mathrm{e}^{-}+4 \mathrm{H}^{+} \rightarrow 2 \mathrm{H}_{2} \mathrm{O}
$$

They occur in all types of organisms and typical examples are ceruloplasmin, laccase, ascorbate oxidase, bilirubin oxidase, and the bacterial copper-resistance protein CueO. ${ }^{2,3}$ They can oxidise great range of organic substrates, as well as a number of metal ions ${ }^{1,3}$ and have therefore found use both in biotechnological and bioelectrochemical (biofuel cells) applications. ${ }^{4,5}$

As the name implies, the MCOs contain at least two copper sites. The substrate oxidation takes place close to a type 1 (blue) copper site, in which a single copper ion is bound to a cysteine (Cys) and two histidine (His) residues, and in some proteins also to a methionine residue. The $\mathrm{O}_{2}$ molecule binds to a trinuclear copper cluster (TNC), in which one copper ion (the type 2 copper ion, $\mathrm{Cu}_{\mathrm{T} 2}$ ) is bound to two His residues and to one solvent molecule (water or $\mathrm{OH}^{-}$), whereas the other two $\mathrm{Cu}$ ions (the type 3 copper ions, $\mathrm{Cu}_{\mathrm{T} 3}$ ) bind to three His ligands each, and possibly to additional solvent or $\mathrm{O}_{2}$-derived molecules. The eight His ligands of the TNC occur pair-wise in the amino-acid sequence (four His-X-His motifs) and in one case, the $\mathrm{X}$ residue is the Cys ligand of the type $1 \mathrm{Cu}$ ion $\left(\mathrm{Cu}_{\mathrm{T} 1}\right)$, providing a favourable path for the transfer of electrons between the two sites, which are at a $\mathrm{Cu}-\mathrm{Cu}$ distance of $\sim 13 \AA$.

The MCOs have been extensively studied by both experimental ${ }^{1,3,6-11}$ and theoretical ${ }^{10-13}$ methods. Crystal structures are available from $\sim 20$ different organisms. ${ }^{1,-8,13-15}$ In the oxidised resting state of the enzyme, all three copper ions of the TNC are in the oxidised Cu $\mathrm{Cu}^{\text {II }}$ state and the two $\mathrm{Cu}_{\mathrm{T} 3}$ ions are bridged by a $\mathrm{OH}^{-}$molecule. In the reduced state, the three TNC copper ions are in the reduced $\mathrm{Cu}^{\prime}$ state and there is no ligand bridging the two $\mathrm{Cu}_{\mathrm{T} 3}$ ions. This is the state that binds the $\mathrm{O}_{2}$ molecule.

By ingenious spectroscopic studies, Solomon and coworkers have characterised two intermediates in the catalytic mechanism of the MCOs. ${ }^{1,3,11}$ Directly after the binding of $\mathrm{O}_{2}$ to the TNC, a peroxide intermediate (PI) is formed, in which two $\mathrm{Cu}$ ions are oxidised to $\mathrm{Cu}^{\prime \prime}$ and $\mathrm{O}_{2}$ is reduced to the peroxide level. ${ }^{16}$ Theoretical calculations suggested that the peroxide binds in the centre of the TNC in a diagonal manner $\left(\mu_{3}-1,1,2\right)$, interacting with all three $\mathrm{Cu}$ ions ${ }^{12,17-19}$ and this was later confirmed by combined experimental and computational studies ${ }^{20,21}$. Rotation of the $\mathrm{O}_{2}{ }^{2-}$ ion in the TNC is facile both in isolated clusters and in the protein. ${ }^{22}$

A second state, the native intermediate ( $\mathrm{NI})$, has also been identified experimentally and was shown to contain four oxidised $\mathrm{Cu}$ ions and the $\mathrm{O}_{2}$ substrate fully reduced to the level of two water molecules. ${ }^{23}$ Theoretical calculations indicated that it consists of an $\mathrm{O}^{2-}$ ion bound symmetrically in the centre of the TNC $\left(\mu_{3}\right),{ }^{12,17,19}$ which was later confirmed by other studies ${ }^{10,24}$. Interestingly, $\mathrm{NI}$ is the only fully oxidised state in the catalytic cycle of the enzyme, whereas the oxidised resting state seems to be outside this cycle, as the conversion of the $\mathrm{NI}$ to the oxidised resting state has been shown to be too slow to comply with the overall catalytic turnover. ${ }^{10,11,25}$

Based on these findings, a reaction mechanism of the MCOs was postulated, shown in Figure $1 .^{1,10-13}$ It starts with $\mathrm{O}_{2}$ binding to the reduced state, accompanied with the transfer of two electrons from two $\mathrm{Cu}^{\prime \prime}$ ions to $\mathrm{O}_{2}$, directly leading the PI. Next, an electron is transferred from $\mathrm{Cu}_{\mathrm{T} 1}$ to the TNC, resulting in the transient $\mathrm{NI}$ species in the $\mathrm{Cu}^{\prime \prime} \mathrm{Cu}_{2}^{\prime}$ state. This triggers the cleavage of the $\mathrm{O}-\mathrm{O}$ bond and the formation of the NI. The latter step has been studied in detail with quantum-mechanical $(\mathrm{QM})$ and $\mathrm{QM} / \mathrm{MM}$ methods, ${ }^{20,26}$ showing a relatively facile reaction (with estimated barriers of $20-60 \mathrm{~kJ} / \mathrm{mol}$ ). Finally, the reduced state should be regenerated by the transfer of three more electrons from $\mathrm{Cu}_{\mathrm{T} 1}$ to the TNC. These electron transfers should be accompanied also by proton transfers (ultimately from the surrounding solvent). However, relatively little information is available for the detailed structure of the states between $\mathrm{NI}$ and the reduced state, or on the exact protonation of the water- and $\mathrm{O}_{2}$ - derived ligands of the TNC. An alternative resting state has been observed and characterized in bilirubin oxidase by spectroscopy and crystallography, indicating a TNC in the $\mathrm{Cu}(\mathrm{I})_{2} \mathrm{Cu}(\mathrm{II})$ state, with the two $\mathrm{Cu}_{\mathrm{T}}$ ions bridged by an oxygen ligand with a long $\mathrm{Cu}-\mathrm{Cu}$ distance $(5.0 \AA) .{ }^{27}$ Similar crystal structures have also been published by other groups, in which the two $\mathrm{Cu}_{T 3}$ ions are bridged by either one or two oxygen 
atoms ${ }^{28,29}$ but it is likely that at least some of them are the affected by partial photoreduction of the TNC during data collection (i.e. showing a mixture of several different oxidation states). ${ }^{13}$ Solomon and coworkers have studied the one-electron reduction of the native intermediate, giving rise to the $\mathrm{Cu}(\mathrm{I}) \mathrm{Cu}(\mathrm{II})_{2}$ state. ${ }^{25}$ Very recently, they have also published a combined kinetic, electron paramagnetic resonance (EPR) and QM study of all states involved in the conversion of $\mathrm{NI}$ to the fully reduced state. ${ }^{30}$

As already discussed, the reduction of $\mathrm{O}_{2}$ involves the uptake of four electrons and four protons. The electrons are transported to the TNC via the $\mathrm{Cu}_{\mathrm{T} 1}$ site and they are taken from the substrates, which are oxidised at the $\mathrm{Cu}_{\mathrm{T} 1}$ site. The protons are taken from solution and are most likely transported to the TNC via two conserved residues, Asp-112 (throughout this article, we use the residue numbering of $\mathrm{CueO}^{15}$ ), which is connected to $\mathrm{Cu}_{\mathrm{T} 2}$ via two water molecules, and Glu506 , which is connected to the ligand bridging the two $\mathrm{Cu}_{\mathrm{T} 3}$ ions via a water molecule. Differences involving electrons and protons are very hard to discern in crystal structures. Unfortunately, reactions involving a change in the number of electrons or protons are also hard to study by theoretical methods, because the net charge of the system changes. This gives rise to large and long-ranged electrostatic energies and huge solvation effects. ${ }^{31}$ For example, the Coulombic interaction between two groups with a unit charge at a distance of $15 \AA$ is $93 \mathrm{~kJ} / \mathrm{mol}(0.96 \mathrm{eV}$; although it is probably screened by a dielectric constant of 4-80) and the Born solvation energy in water of a unit charge is $23 \mathrm{~kJ} / \mathrm{mol}(0.24 \mathrm{~V})$ even for a spherical system with a radius $30 \AA$ (i.e. similar to the size of a MCO). This makes the calculation of absolute redox potentials and acidity constants of protein sites a formidable task. Further complications arise from the fact that there are large differences in the electron-correlation energies when the number of electrons in a metal change, leading to large differences in reduction potentials calculated with different densityfunctional theory (DFT) methods. ${ }^{32,33}$

Many methods to calculate the redox potentials of metal sites in proteins have been developed. A first estimate can be obtained by simply calculating the QM energies of the activesite clusters in a continuum solvent. However, to obtain information on the influence of the surrounding protein, more sophisticated methods are needed. ${ }^{30,32,34-38}$ In particular, several groups have estimated and rationalised the redox potentials of $\mathrm{Cu}_{T 1}$ sites in proteins ${ }^{36,39-42}$ and the TNC in MCOs has also been studied. ${ }^{43}$

Likewise, many methods have been developed to calculate acidity constants, both of small molecules in solution and of various groups in proteins. ${ }^{33,34,44-49}$ The former are typically based on QM calculations, to obtain the intrinsic proton affinity of the molecules of interest, combined with continuum-solvation methods to estimate the effect of transferring the reactants from vacuum to solvent. In proteins, the intrinsic proton affinity is often of less interest; instead, the main issue is how the protein alters the acidity constant of a group relative to water solution (for which the acidity constant typically is known). Many approaches have been suggested and tested for the calculation of the differential solvation effect in the protein, based on e.g. free-energy perturbations (FEP) or continuum-solvation models, using the Poisson-Boltzmann (PB), the Langevin dipole (LD) approach, or the generalised Born (GB) methods. ${ }^{34,47,50,51}$ In general, an accuracy of one or a few $\mathrm{pK}_{\mathrm{a}}$ units is claimed. ${ }^{33,44,47}$ Fewer groups have tried to estimate the acidity constants of metal-bound ligands, mainly because of the large effect of the charged metal and the fact that it is difficult to model metals by molecular-mechanical (MM) methods. However, several attempts have been made, especially for metal-bound water molecules, using the LD and PB methods. ${ }^{32,34,52-54}$

In this work, we study electron- and proton transfer reactions in the reaction cycle of the MCOs with the help of FEP calculations at the combined QM and MM (QM/MM) level. By estimating redox potentials, acidity constants, isomerisation free energies, as well as $\mathrm{O}_{2}$ and water-binding free energies of putative intermediates, we obtain information about the most likely steps in the reaction mechanism, especially for the regeneration of the reduced state from the NI.

\section{Methods}

The protein

The calculations on the MCOs are based on the 1.4- $\AA$ crystal structure of CueO (PDB code $1 \mathrm{KV} 7) .{ }^{15} \mathrm{CueO}$ is a bacterial copper homeostasis factor and this structure was selected because of 
its high resolution and that it lacks the extended glycosylation found for most eukaryotic MCOs. In addition, we have already performed extensive theoretical studies on this protein. ${ }^{12,13,17-19,26}$ The whole protein was included in all calculations, as well as a large number of surrounding water molecules. Initially, all Glu and Asp residues were assumed to be deprotonated and all Lys and Arg residues were assumed to be protonated. The protonation state of the His residues were assigned based on their solvent exposure, the hydrogen-bond network, and the local surroundings: ${ }^{12}$ Eight His residues on the protein surface were assumed to be protonated on both $\mathrm{N}$ atoms (His-145, 224, 314, 405, 406, 465, 488, and 494), whereas the remaining ten His residues, which are ligands of the $\mathrm{Cu}$ ions, were assumed to be protonated on the $\mathrm{N}$ atom not coordinating to the metal. The Cys ligand of $\mathrm{Cu}_{T 1}$ was assumed to be deprotonated. This gave a net charge of the full simulated system of -1 to $+4 e$, depending on the studied state of the two copper sites. No counter-ions were used in the simulations.

In some simulations, we also tested to neutralise all solvent-exposed charged groups, as has often been done in calculations of reduction potentials or acidity constants. ${ }^{36,44,52}$ The solvent exposure was determined from the contact of each residue with water molecules during molecular dynamics (MD) simulations ${ }^{32}$ and it was also checked by the number of protein atoms surrounding the groups ${ }^{20}$ and by visual inspection. We decided to keep the charge on 17 buried residues: Arg232, 234, 242, 280, and 466, Lys-188 and 470, Asp-112, 180, 187, 260, 439, and 471, as well as Glu-279, 282, 457, and 506. Of these, Asp-112, 439, 471, form hydrogen bonds to His ligands of the copper sites and Glu-506 interacts with the TNC bridging ligand via a water molecule. All the other residues form ionic pairs with each other, except Lys-188, which is deeply buried in the protein, but the closest carboxylate group is four hydrogen bonds away. All the other (exposed) groups were neutralised by adding or removing a proton, using the AMBER neutralised residues $\mathrm{ASH}, \mathrm{GLH}$, and LYN and a neutralised Arg model. ${ }^{55}$ All sites were visually inspected so that protons were added or removed on proper positions to optimise the hydrogen-bond networks.

\section{The QM/MM-2QM approach}

For the QM/MM geometry optimisations, the QM/MM-2QM approach was employed, ${ }^{37,43}$ in which the two copper sites were both treated by $Q M$, but in separate $Q M$ calculations. This is possible because the two copper centres are $\sim 13 \AA$ apart. The QM/MM-2QM implementation was based on the COMQOM program ${ }^{56,57}$ which is an interface between the Turbomole ${ }^{58}$ and Amber $^{59}$ softwares.

In this $\mathrm{QM} / \mathrm{MM}-2 \mathrm{QM}$ approach, the protein and solvent are divided into three subsystems: the two QM systems (systems 1a and 1b) and the MM system (system 2). In the QM calculations, systems $1 \mathrm{a}$ and $1 \mathrm{~b}$ are represented by a wavefunction, whereas all the other atoms are represented by an array of partial point charges, one for each atom, taken from MM libraries. Thereby, the polarisation of the QM system by the surroundings is included in a self-consistent manner (electrostatic embedding, EE). In the QM/MM calculations, the MM system was kept fixed at the original (crystallographic) coordinates (but it was relaxed in the subsequent QTCP calculations, described in the next section).

When there is a bond between systems 2 and $1 \mathrm{a}$ or $1 \mathrm{~b}$ (a junction), the hydrogen link-atom approach is employed: The QM region is truncated by hydrogen atoms (called hydrogen link atoms, $\mathrm{HL}$ ), the positions of which are linearly related to the corresponding carbon atoms in the full system (called carbon link atoms, CL). ${ }^{56}$ In the point-charge model of the surroundings, all atoms were included, except the CL atoms. ${ }^{60}$ For our QM systems, the CB atom of the His and Met $\mathrm{Cu}$ ligands and the $\mathrm{CA}$ atom of the Cys ligand were replaced by $\mathrm{HL}$ atoms. In the proton-transfer reactions, the CA atom of Asp-373 was replaced by a $\mathrm{HL}$ atom.

The total QM/MM-2QM energy was calculated in the following way:

$$
E_{Q M / M M-2 Q M}^{E E}=E_{Q M 1 a+p t c h 1 b 2}^{H L}-E_{M M 1 a, q=0}^{H L}+E_{Q M 1 b+p t c h 1 a 2}^{H L}-E_{M M 1 b, q=0}^{H L}+E_{M M 1 a b 2, q_{1 a}=q_{1 b}=0}^{C L}
$$

Here, $E_{Q M 1 a+p t c h 1 b 2}^{H L}$ is the QM energy of system 1a, truncated with $\mathrm{HL}$ atoms, and including a pointcharge model of the surrounding protein (also of system $1 \mathrm{~b}$ ) in the one-electron Hamiltonian. $E_{Q M 1 b+p t c h 1 a 2}^{H L}$ is the corresponding QM energy for system $1 \mathrm{~b} . E_{M M 1 a, q=0}^{H L}$ and $E_{M M 1 b, q=0}^{H L}$ are the MM 
energies of systems $1 \mathrm{a}$ and $1 \mathrm{~b}$ (still with $\mathrm{HL}$ atoms), but with all charges zeroed. Finally, $E_{M M 1 a b 2, q_{1 a}=q_{1 b}=0}^{C L}$ is the MM energy of all systems with $C L$ atoms, but with the charges of the two QM systems zeroed (because all electrostatics interactions within the QM systems and between the QM and MM systems are considered in the two QM terms. However, the electrostatic interactions between the two QM systems is still accounted for in both $E_{Q M 1 a+p t c h 1 b 2}^{H L}$ and $E_{Q M 1 b+p t c h 1 a 2}^{H L}$. This problem was solved by scaling down the point charges of the other QM system by a factor of 2 in both terms. ${ }^{43}$

The point-charge model of each QM system was obtained by a fit to the electrostatic potential (ESP) calculated for a wavefunction polarised by a point-charge model of the surroundings, but without the point charges when the ESP was calculated. ${ }^{43,61}$ The ESP points were sampled with the Merz-Kollman approach ${ }^{62}$ as implemented in Turbomole ${ }^{58}$. The charges were updated in each step of the geometry optimisation. The QM/MM-2QM calculations were performed on spherical systems in which the whole CueO protein was solvated in a $38-\AA$ sphere of explicit water molecules ( 21000 atoms in total). ${ }^{13}$

\section{QTCP-2QM calculations}

Based on the QM/MM-2QM optimised structures, we used the QTCP (QM/MM thermodynamic cycle perturbation) approach ${ }^{63,64}$ to calculate the various reaction free energies. This is a method to calculate free energies with a high-level QM/MM method, using sampling only at the computationally cheaper MM level. It calculates the free energy from three separate terms:

$$
\Delta G_{\mathrm{QTCP}}(\mathrm{R} \rightarrow \mathrm{P})=-\Delta G_{\mathrm{MM} \rightarrow \mathrm{QM} / \mathrm{MM}}(\mathrm{R})+\Delta G_{\mathrm{MM}}(\mathrm{R} \rightarrow \mathrm{P})+\Delta G_{\mathrm{MM} \rightarrow \mathrm{QM} / \mathrm{MM}}(\mathrm{P})
$$

where $R$ and $P$ are the reactant and product states. Thus, the free energy difference between $P$ and $R$ is calculated with a normal FEP calculation at the MM level. Then, additional FEP calculations are performed from the MM to the QM/MM levels, one for the $R$ state and one for the $P$ state. To obtain stable $M M \rightarrow Q M / M M$ free energies, the $Q M$ systems are kept fixed in the MD simulations. Test calculations at the semiempirical level have shown that this is does not affect the final free energies significantly. ${ }^{65}$

The QTCP-2QM calculations were performed as previously described: ${ }^{32,43,63,64,66}$ First, each state was optimised by $\mathrm{QM} / \mathrm{MM}-2 \mathrm{QM}$, as described in the previous section. Second, the total system was moved into a periodic octahedral box and was further solvated with water molecules extending at least $9 \AA$ from the original system, giving a total of $\sim 12300$ water molecules or $\sim 43000$ atoms. For the reactant state, the system was first subjected to a 1000-step minimisation, keeping the QM systems fixed and all heavy atoms except water molecules restrained towards their positions in the crystal structure with a force constant of $418 \mathrm{~kJ} / \mathrm{mol} / \AA^{2}$. Then, a $20-p s$ constant-volume MD simulation was run with only the heavy atoms restrained, but with a force constant of $2092 \mathrm{~kJ} / \mathrm{mol} / \AA^{2}$. Next, a 20-ps constant-pressure MD simulation was run with the same constraints but a force constant of $418 \mathrm{~kJ} / \mathrm{mol} / \AA^{2}$. Finally, the box size was equilibrated by a $100-$ ps MD simulation with a constant pressure and only the heavy atoms of the two QM systems restrained to the $Q M / M M-2 Q M$ structure with a force constant of $418 \mathrm{~kJ} / \mathrm{mol} / \AA^{2}$. The final structure of this simulation was then used as the starting structure for the simulations of the other state. It is not possible to keep the QM atoms exactly fixed in the constant-pressure simulations. Therefore, the QM atoms were moved back to the QM/MM structure before an equilibration of 200 ps and a production simulation of 400 ps were run with a constant volume and with the two QM systems fixed. During the production run, 200 snapshots were collected every 2 ps. Finally, free energies were estimated from these snapshots, using FEP or thermodynamic integration (TI). FEP free energies and their uncertainties were estimated by cumulant expressions. ${ }^{65,67}$

Several methods were used to estimate long-range electrostatic effects outside the simulated system. The results presented in the text and the tables were obtained with periodic systems and Ewald summation (as in the MD simulations). However, non-periodic calculations with an infinite cut-off and solvation energies outside the simulated system calculated by the Onsager or Born models ${ }^{32,}{ }^{68}$ give results that differ by only a few $\mathrm{kJ} / \mathrm{mol}$ (isomerisation free energies coincide within $1 \mathrm{~kJ} / \mathrm{mol}$, O-O bond cleavage reaction free energies differ by $1-3 \mathrm{~kJ} / \mathrm{mol}$, 
the reduction potentials are typically $0.04 \mathrm{~V}$ more positive, and the acidity constants differ by 1.4 $\mathrm{p} K_{\mathrm{a}}$ units on average). However, if the long-range solvation effects were instead estimated with the generalised Born method, ${ }^{69}$ much larger differences were often encountered (results not shown).

The perturbations were divided into several steps, depending on the type of energies studied, as is illustrated in Figure 2. Reduction potentials were studied by transferring an electron from the $\mathrm{Cu}_{\mathrm{T} 1}$ site to the TNC (i.e. between the two QM systems). Such a reaction does not change the net charge of the protein, thereby making the calculated energies more stable. We performed nine simulations with the charges of the QM system linearly transformed from the reactant state to the product state by a coupling parameter, $\lambda$, assuming the values of $0,0.125$, $0.25,0.375,0.5,0.625,0.75,0.875$, and 1 . This was accomplished by simply changing the charges in the parameter file, whereas the coordinates of the QM system were kept to those of the reactant state. Free energies were estimated by TI. Then, the coordinates of the QM system were perturbed from that of the reactant state to that of the product state, using charges of the product state. This was accomplished in five FEP simulations using another coupling parameter attaining the values of $0,0.25,0.5,0.75$, and 1 . For the two end states (reactant and product states), we also performed a perturbation from $\mathrm{MM}$ to $\mathrm{QM} / \mathrm{MM}-2 \mathrm{QM}$ energies, as has been detailed before. ${ }^{32}$, 43, 64 These calculations were performed on the same octahedral systems as all the other QTCP2QM calculations, but without any periodicity or Ewald summation and instead with an infinite cutoff. We studied the $\mathrm{O}-\mathrm{O}$ cleavage reaction in the same way (but without transferring any electron, so that the $\mathrm{Cu}_{\mathrm{T} 1}$ site was not affected by the reaction).

For the acidity calculations, we instead transferred a proton from the TNC to a carboxylate group on the surface of the protein (which now was the other QM system, whereas the $\mathrm{Cu}_{T 1}$ site was part of the MM system). After a set of test calculations (described in Table S1 in the supporting information), we decided to use Asp-373 as the proton acceptor. It is located on the surface of the protein, without any interactions with other protein residues and it is $\sim 24 \AA$ from $\mathrm{Cu}_{\mathrm{T} 1}$ and $34-37 \AA$ from the $\mathrm{Cu}$ ions in the TNC. When the residue was protonated, only charges in the QM system (an acetate ion) were modified, whereas the charges on the protein back-bone ( $N$, $\mathrm{H}, \mathrm{HA}, \mathrm{C}$, and $\mathrm{O}$ atoms) were the same as for a normal negatively charged Asp residue.

The movement of a proton is a more complicated reaction, involving disappearance and appearance of atoms. ${ }^{32}$ We started from a protonated TNC and a deprotonated Asp-373 residue. Then, we introduced a dummy atom on Asp-373, calculating its contributions to the free energy analytically from local configurational integrals. ${ }^{32,70,71} \mathrm{Next}$, the van der Waals parameters of this appearing proton were perturbed from those of a dummy atom with a zeroed a theoretical depth to polar hydrogen by a single-step perturbation. After that, the charges of the two QM sites were perturbed from those of the starting state to those of the final state (and zero charges for the disappearing protons) in nine steps, in the same way as for the electron-transfer reactions (keeping the geometry and van der Waals parameters fixed). Subsequently, the van der Waals parameters of the disappearing proton of the TNC were perturbed from those of a polar hydrogen to a dummy atom with a zeroed well-depth in a single step. Next, the resulting non-interacting dummy atom was deleted, again calculating its contributions to the free energy analytically. In fact, the two analytical contributions will cancel in the net result. Finally, the coordinates of the two QM systems were transformed from those of the starting state (without the dissociating proton) to those of the final state in five steps, as described above. The same approach was used for isomerisation reactions, for which a proton was moved within the TNC cluster $\left(a \mathrm{Cu}_{\mathrm{T} 1}\right.$ site was included as the other QM system, although it was not explicitly involved in the reaction).

All calculations where automatized and performed by four Linux shell scripts and a number of Fortran programs that are available from the authors upon request. Some further details of the calculations can be found in http://www.teokem.lu.se/ ulf/Methods/qtcp.html.

\section{QM/MM-PBSA-2QM calculations}

The QM/MM-PBSA method ${ }^{43,} 61$ can be viewed as a post-processing of $Q M / M M$ calculations to obtain more stable energies, including a solvation energy obtained by continuum solvation methods. It is an adaptation of the widely used MM/PBSA approach ${ }^{72}$ for QM/MM calculations. In this approach, an approximation to the total free energy for each state is obtained from: 


$$
G=E_{Q M / M M-2 Q M}^{M E}+G_{S o l v}+G_{n p}-T S_{Q M / M M}
$$

Here

$$
E_{Q M / M M-2 Q M}^{M E}=E_{Q M 1 a}^{H L}-E_{M M 1 a}^{C L}+E_{Q M 1 b}^{H L}-E_{M M 1 b}^{C L}+E_{M M 1 a b 2}^{C L}
$$

where $E_{Q M 1 a}^{H L}$ and $E_{Q M 1 b}^{H L}$ are the QM energy of the two QM systems, truncated with $\mathrm{HL}$ atoms, but without any point-charge model. $E_{M M 1 a}^{C L}$ and $E_{M M 1 b}^{C L}$ are the corresponding MM energies of the two QM systems, but now with $C L$ atoms and with full charges. Finally, $E_{M M 1 a b 2}^{C L}$ is the MM energy of the total system with $C L$ atoms and full charges. This energy is similar to the QM/MM-2QM energy in Eqn. (1), but it instead employs mechanical embedding (ME), i.e. the electrostatic interactions between the QM and MM systems are calculated at the MM level. $G_{\text {solv }}$ is the polar solvation energy, estimated by a continuum approach, obtained either by the generalised Born (GB) approach developed by Onufriev, Bashford and Case (model II, i.e. igb $=5)^{69}$ or by solving the Poisson-Boltzmann (PB) equation using the PB solver in Amber. ${ }^{59} G_{n p}$ is the non-polar solvation energy, estimated from the solvent-accessible surface area (SASA), through the linear relation $G_{n p}$ $=0.0227$ SASA $\left(\AA^{2}\right)+3.85 \mathrm{~kJ} / \mathrm{mol}^{73}$ The entropy term was ignored, because entropy effects are expected to be quite small in these electron- and proton-transfer reactions. ${ }^{43}$

Two variants of QM/MM-PBSA-2QM were tested. They differ in how the QM energy and the charges on the QM atoms are calculated. ${ }^{32,43,66}$ In the first approach, the QM energy and the charges are calculated from a vacuum wavefunction. In the second approach, the QM wavefunction is optimised with a point-charge model of the other systems. However, the final energy and the QM charges are calculated without this point-charge model and without reoptimising the wavefunction (obtained by setting the number of SCF iterations to 1 and using the final DFT integration grid in this single step). Thereby, the QM system is polarised by the MM surroundings and the cost of the polarisation is included in the calculations.

The QM/MM-PBSA-2QM calculations were based on the spherical QM/MM-2QM structures. The calculations were automatized and performed by Linux shell scripts, which are available from the authors on request. Further details of the calculations can be found in http://www.teokem.lu.se/ ulf/Methods/qmmm_pbsa.html.

Throughout this article, the presented results are from the QTCP method if available, which are the most accurate. However, $\mathrm{O}_{2}$ and $\mathrm{H}_{2} \mathrm{O}$ binding energies are harder to estimate with QM/MM-FEP methods (owing to the dissociation ligand); therefore, the reported results are from the QM/MM-PB(GB)SA-2QM calculations and the same applies to the more approximate absolute redox potentials. Naturally, the latter methods also give results for the other types of calculations. Our results show that QM/MM-PBSA-2QM typically gives a somewhat larger variation in the results than QTCP, whereas QM/MM-GBSA-2QM often gives a smaller variation. However, for the most of the redox, isomerisation, and $\mathrm{O}-\mathrm{O}$ bond- cleavage reactions, all methods indicate the same direction of the reaction, increasing the credibility of the calculated results. For the protontransfer reactions, the QM/MM-GBSA results are consistently more negative than the QTCP results (by 14-21 $\mathrm{pK}_{\mathrm{a}}$ units on average), whereas the QM/MM-PBSA results are more positive (by 10-12 $\mathrm{pK}_{\mathrm{a}}$ unit on average). This shows that there is a difference in how the three methods estimate the change in the solvation energy when the charge of a site changes by one unit when one site is solvent exposed and the other is buried in the protein. QM/MM-2QM results are also available for all reactions, but they in general overestimate variations by a factor of about two, owing to the missing dynamic and long-range solvation effects, and they are therefore not discussed.

To examine the effect of the neutralisation of the surface charges (employed for the protontransfer and isomerisation reactions, but not for the redox potentials), we repeated one of the QTCP redox calculations with neutralised surface charges. Quite encouragingly, the predicted redox potential changed by only $0.18 \mathrm{~V}$ when the surface charges were neutralised. The effect is similar for the QM/MM-GBSA calculations, in which the calculated redox potentials changed by $0.18 \mathrm{~V}$ on average for all 21 systems. The effect is even smaller for the proton-transfer reaction, less than $0.8 \mathrm{pK}_{\mathrm{a}}$ units. Consequently, we think that the present results can be trusted to within 30 
$\mathrm{kJ} / \mathrm{mol}(0.3 \mathrm{eV}$ or $5 \mathrm{pK}$ units), except for states for which there is a large difference in the results obtained with the different DFT functionals (in particular the $\mathrm{O}_{2}$ binding free energies).

\section{QM calculations}

QM/MM-2QM optimisations and the QTCP-2QM calculations were performed with the Perdew-Burke-Ernzerhof (PBE) density functional ${ }^{74}$ and the def2-SVP basis set. ${ }^{75}$ These energies $^{7}$ were then improved by single-point energy calculations with the hybrid B3LYP method ${ }^{76,77}$ and the larger def2-TZVPD basis set with diffuse functions on all atoms ${ }^{75,78}$ All QM calculations were sped up by expanding the Coulomb interactions in an auxiliary basis set, the resolution-of-identity (RI) approximation. ${ }^{79,80}$ Test calculations (cf. Table S2 in the supplementary material) showed that the def2-TZVPD basis set gives reaction energies (isomerisation, redox potentials, acidity constants, and $\mathrm{O}-\mathrm{O}$ cleavage reaction energies) that are converged to within $3 \mathrm{~kJ} / \mathrm{mol}$ compared to calculations with the even larger def2-QZVPD basis set. Diffuse functions are needed to give such accurate energies for the acidity constants and redox potentials - the def2-TZVP basis set gives errors of up to $14 \mathrm{~kJ} / \mathrm{mol}$. All QM calculations were performed with the Turbomole 6.5 software ${ }^{58}$.

Dispersion effects were included by the DFT-D3 approach ${ }^{81}$ with Becke-Johnson damping ${ }^{82}$ and third-order terms, calculated with the dftd3 program ${ }^{83}$ Results presented in the text and the tables were obtained at the B3LYP-D3/def2-TZVPD level of theory. The dispersion correction is in generally modest for isomerisation, electron- and proton-transfer reactions (3-5 $\mathrm{kJ} / \mathrm{mol}$ absolute average with a varying sign). However, for the $\mathrm{O}-\mathrm{O}$ cleavage, $\mathrm{O}_{2}$ binding, and the $\mathrm{H}_{2} \mathrm{O}$-dissociation reactions it is large and significant $(-24,-35$ and $22 \mathrm{~kJ} / \mathrm{mol}$ on average, respectively).

We used an acetate model for Asp-373, a Cu(imidazole $)_{2}\left(\mathrm{CH}_{3} \mathrm{~S}\right)\left(\mathrm{CH}_{3} \mathrm{SCH}_{3}\right)$ model for the $\mathrm{Cu}_{\mathrm{T} 1}$ site, and $\mathrm{C} \mathrm{Cu}_{3}$ (imidazole) $)_{8}$ model for the TNC cluster with a variable number of water- and $\mathrm{O}_{2}$-derived ligands. A water molecule hydrogen-bonded to the ligand bridging the two $\mathrm{Cu}_{\mathrm{T} 3}$ atoms was included in all systems. ${ }^{12}$ Typical examples of both sites are shown in Figure 3 . The $\mathrm{Cu}_{\mathrm{T} 1}$ site was studied in both the oxidised and reduced states, with a net charge of either zero or one, and with no or one unpaired electron, respectively. For the TNC, all possible oxidation states between $\mathrm{Cu}(\mathrm{I})_{3}$ and $\mathrm{Cu}(\mathrm{II})_{3}$ were studied with unrestricted formalism. With more than one $\mathrm{Cu}(\mathrm{II})$ ion, the antiferromagnetically coupled state with no or one unpaired electron ${ }^{13}$ was studied using the broken-symmetry approach ${ }^{84}$ for all calculations, both geometry optimisations and single-point energy calculations.

\section{MM and MD calculations}

All MM and MD calculations were carried out with the sander module in the Amber 10 software ${ }^{59}$ using the Amber 99SB force field. ${ }^{85}$ The bond lengths involving hydrogen atoms were constrained using the SHAKE algorithm. ${ }^{86}$ The electrostatics were treated using the particle-mesh Ewald method ${ }^{87,88}$ with a grid size of $80^{3}$, a fourth-order B-spline interpolation, a tolerance of $10^{-5}$, and a real-space cut-off of $8 \AA$. The temperature was kept constant at $300 \mathrm{~K}$ and the pressure was kept constant at $1 \mathrm{~atm}$ using the Berendsen weak-coupling algorithm ${ }^{89}$ with a time constants of 1 ps in both cases. The MD time step was 2 fs and the non-bonded pair list was updated every 50 fs. All MD simulations were performed with explicit water molecules, using the TIP3P water model. ${ }^{90}$

\section{Result and Discussion}

In this paper, we study the full catalytic cycle of the MCOs using theoretical methods. We have optimised 52 putative intermediates in the reaction mechanism using the QM/MM-2QM method and have subsequently used the QTCP-2QM approach to obtain accurate energies for the various steps. The QTCP-2QM results were compared to the corresponding $\mathrm{QM} / \mathrm{MM}-2 \mathrm{QM}$ and QM/MM-PBSA-2QM energies to confirm that reliability and consistency of the results. Our focus has been to study possible electronic and protonation states, in particular during the reformation of the reduced state of the TNC from the native intermediate. 
According to the current consensus mechanism, ${ }^{1,13}$ the resting oxidised state $(\mathrm{Ox})$ involves a $\mathrm{Cu}(\mathrm{II})_{3}$ cluster for the TNC with a hydroxide ion coordinated to $\mathrm{Cu}_{\mathrm{T} 2}$ and another hydroxide ion bridging between the two $\mathrm{Cu}_{\mathrm{T} 3}$ ions. Likewise, the reduced state (Red) contains a $\mathrm{Cu}(\mathrm{I})_{3}$ cluster with a water molecule or hydroxide ion coordinated to $\mathrm{Cu}_{\mathrm{T} 2}$ and no bridging ligand between the two $\mathrm{Cu}_{\mathrm{T} 3}$ ions. ${ }^{14}$ The $\mathrm{PI}$ is formed directly from the Red state and it contains a $\mathrm{O}_{2}{ }^{2-}$ ion bound in the centre of the TNC in a diagonal manner. Finally, in the NI, the O-O is cleaved and one of the $\mathrm{O}^{2-}$ ions is bound in the centre of the TNC, whereas the other $\mathrm{O}$ atom is probably protonated and bridges the two $\mathrm{Cu}_{\mathrm{T} 3}$ ions. These four states constitute the starting point of the present investigation and they are shown in Figure 3. Except for the Ox state, the protonation state of the $\mathrm{Cu}_{\mathrm{T} 2}$ ligand is uncertain (for simplicity, we have used a hydroxide ligand for the other states in the figure).

In this study, we have tried to connect these states by adding electrons or protons and letting water molecules dissociate. In principle, the TNC in the NI state should be connected to the Red state by the addition of three electrons and three protons (the fourth electron and proton are transferred to the TNC during the conversion of the $\mathrm{PI}$ to the $\mathrm{NI}$ ). Apparently, there are two intermediate oxidation states of the TNC between $\mathrm{NI}$ and Red (note that $\mathrm{NI}$ is at the same oxidation level as the $\mathrm{Ox}$ state): $\mathrm{IOx}$ with $\mathrm{Cu}(\mathrm{II})_{2} \mathrm{Cu}(\mathrm{I})$ and IRed with $\mathrm{Cu}(\mathrm{II}) \mathrm{Cu}(\mathrm{I})_{2}$. To simplify the discussion, we have used the following nomenclature to describe the various states: First the oxidation state of the TNC is specified by giving the state (Red, IRed, IOx, NI, PI, or Ox; we use NI' for the one-electron reduced $\mathrm{PI}$, i.e. the $\mathrm{NI}$ state before the $\mathrm{O}-\mathrm{O}$ bond is cleaved, sometimes denoted $\mathrm{PI}+\mathrm{e}$ ). Then, the ligands (without formal charges) are given within brackets in the order $\mathrm{Cu}_{\mathrm{T} 2}$ ligand, (i.e. the ligand binding only to $\mathrm{Cu}_{\mathrm{T} 2}$ ), the ligand bridging the two $\mathrm{Cu}_{\mathrm{T}}$ ions, and possibly a central ligand interacting with all three TNC Cu ions. If only two ligands are given, the central ligand is missing for IOx, IRed, and Red, but the bridging ligand for $\mathrm{PI}$ and $\mathrm{NI}$ '. With this nomenclature, the four states shown in Figure 3 are $\mathrm{Ox}(\mathrm{OH}, \mathrm{OH}), \operatorname{Red}\left(\mathrm{H}_{2} \mathrm{O},-\right), \operatorname{PI}\left(\mathrm{H}_{2} \mathrm{O}, \mathrm{O}_{2}\right)$, and $\mathrm{NI}\left(\mathrm{H}_{2} \mathrm{O}, \mathrm{OH}, \mathrm{O}\right)$.

In total, 52 different states of the TNC were studied (7 Red states, 4 PI states, 4 NI' states, $8 \mathrm{NI}$ states, $13 \mathrm{IOx}$ states, $14 \mathrm{IRed}$ states, and $2 \mathrm{Ox}$ states). They are connected by addition of protons and electrons or dissociation of water molecules in the way illustrated in Figure S1 in the supporting information. In fact, there are additional possible states: We have considered only states with water or $\mathrm{OH}^{-}$as the $\mathrm{Cu}_{\mathrm{T} 2}$ ligand and only states in which the central ligand has the same number of protons or less protons than the bridging $\mathrm{Cu}_{\mathrm{T} 3}$ ligand (because the additional interactions with the copper ions of the former ligand are expected to make it more acidic). After identifying an initial tentative reaction pathway, we have ensured to include all states that differ by one electron, one proton, or by isomerisation, within the above rules. This led to the states included in Figure S1. For all states of the TNC, we have considered structures with both a reduced and an oxidised $\mathrm{Cu}_{\mathrm{T} 1}$ site. Moreover, structures have been obtained both with and without neutralised solvent-exposed charges, as well as with Asp-373 as the second QM system (instead of the $\mathrm{Cu}_{\mathrm{T} 1}$ cluster) in the protonated or deprotonated state.

In the following, we will discuss the electronic structure, the geometries, redox potentials, acidity constants, isomerisation reactions, the chemical reaction of $\mathrm{O}-\mathrm{O}$ cleavage, and $\mathrm{O}_{2}$ and water-binding free energies in separate sections. Finally, we discuss the implications of the present results on the reaction mechanism of the MCOs and how the two copper sites influence each other.

\section{Electronic structure}

We will start by discussing the electronic structure of the various complexes. All Red structures are closed-shell systems, with a well-defined $\mathrm{Cu}(\mathrm{I})_{3}$ state for the TNC. However, for the other states, one (IRed and $\mathrm{NI}$ ), two (IOx and $\mathrm{PI})$, or all three ( $\mathrm{NI}$ and $\mathrm{Ox}$ ) copper ions are formally oxidised, but the unpaired spin on the copper ions are typically delocalised also onto the ligands, especially on those that have a formal negative charge. The electronic structure is further complicated by the fact that all these states, except IRed and $\mathrm{NI}^{\prime}$ are expected to be antiferromagnetically coupled so that the net number of unpaired electrons (in the brokensymmetry approximation) is zero ( $\mathrm{IOx}$ and $\mathrm{PI}$ ) or one ( $\mathrm{NI}$ and $\mathrm{Ox})$. Consequently, the spin density on the oxidised copper ions is typically $0.4-0.7 e$ (and never above $0.80 e$ ). The observed Mulliken 
spin population on the three $\mathrm{Cu}$ ions and the $\mathrm{O}$ ligands are collected in Table $\mathrm{S} 3$ for the various complexes (obtained at the B3LYP/def2-TZVPD level).

The spin density on the $\mathrm{Cu}$ ions is quite varying. For the $\mathrm{Ox}$ states, it is high on all $\mathrm{Cu}$ ions, but slightly lower on $\mathrm{Cu}_{\mathrm{T} 2}$ than on the two $\mathrm{Cu}_{\mathrm{T} 3}$ ions $(0.43-0.58$ and $0.65-0.76 \mathrm{e}$, respectively), although one is negative, reflecting the antiferromagnetic coupling and that all three $\mathrm{Cu}$ ions are oxidised. The $\mathrm{NI}$ states mostly have a similar electronic structure, with rather large spins $(0.29$ 0.56 on $\mathrm{Cu}_{\mathrm{T} 2}$ and $0.47-0.80$ en $\mathrm{Cu}_{\mathrm{T} 3}$, but with varying signs). The only exception is the $\mathrm{NI}\left(\mathrm{H}_{2} \mathrm{O}, \mathrm{O}, \mathrm{O}\right)$ complex, for which the spin is small $(<0.07 \mathrm{e})$ on $\mathrm{Cu}_{\mathrm{T} 2}$. The spin on the copper ions is slightly higher when calculated with the def2-TZVPD basis set than with the def2-SV(P) basis set and typically $\sim 0.25$ e higher when calculated with B3LYP than with PBE and the spin on the ligands is typically also higher.

For eight of the IRed states, one of the copper ions has a larger spin population, indicating that it is oxidised. However, for the other five states, at least two $\mathrm{Cu}$ ions have spin densities of similar magnitude, making it hard to identify the oxidised ion. Likewise, only for nine of the IOx states there is a pair of $\mathrm{Cu}$ ions with a large spin population with opposite spin and a minor population on the third $\mathrm{Cu}$ ion, as expected for a $\mathrm{Cu}(\mathrm{II})_{2} \mathrm{Cu}(\mathrm{I})$ state. For the other states, all $\mathrm{Cu}$ ions have significant spin or one $\mathrm{Cu}$ ion has appreciably more spin than the other two ions.

In the PI state, the spin is typically similar (but with varying signs) on all three copper ions (0.05-0.18 e with $\mathrm{O}_{2}{ }^{2-}$ and $0.18-0.43 e$ with $\mathrm{HO}_{2}^{-}$), making it hard to identify which two copper ions are oxidised. However, the electronic structure seems to be flexible and for some calculations, one $\mathrm{Cu}$ ion has either a larger or lower spin population that the other two. For the $\mathrm{NI}^{\prime}$ states with a $\mathrm{OH}^{-} \mathrm{Cu}_{\mathrm{T} 2}$ ligand, the $\mathrm{Cu}_{\mathrm{T} 2}$ ion is oxidised (0.33-0.48 e spin) and the two $\mathrm{Cu}_{\mathrm{T} 3}$ ions reduced. However, in $\mathrm{Nl}^{\prime}\left(\mathrm{H}_{2} \mathrm{O}, \mathrm{HO}_{2}\right)$, both $\mathrm{Cu}_{\mathrm{T}}$ ions have a high spin $(0.24-0.29 e)$ and in $\mathrm{NI}^{\prime}\left(\mathrm{H}_{2} \mathrm{O}, \mathrm{O}_{2}\right)$, all three $\mathrm{Cu}$ ions have a low spin $(0.00-0.15 e)$.

All the $\mathrm{PI}$ and $\mathrm{NI}$ ' states have a $\mathrm{O}_{2}$-derived ligand in the centre of the cluster. For the $\mathrm{PI}$ states, the spin on this ligand is fairly low $(0.09-0.34 \mathrm{e})$, indicating a rather pure peroxide level, as has been observed before. ${ }^{12}$ However, sometimes larger spin populations are observed for the $\mathrm{HO}_{2}^{-}$ligand (up to $0.49 \mathrm{e}$ ), connected to increased $\mathrm{Cu}$ populations. In the $\mathrm{NI}$ states, the spin on the $\mathrm{O}_{2}$ ligand increases to $0.40-0.74 \mathrm{e}$, indicating an electronic structure more between the peroxide and superoxide levels, except for the $\mathrm{NI}\left(\mathrm{OH}, \mathrm{HO}_{2}\right)$ state for which the spin population decreases from $0.30-0.40$ e to $0.12-0.16 e$.

Water ligands always have only a minimal spin, typically $0.00-0.03 e$, but occasionally up to 0.10 e for the $\mathrm{Cu}_{\mathrm{T} 3}$ ligands in a few complexes.

$\mathrm{O}^{2-}$ ligands have a spin that varies with the oxidation state of the TNC. For the IOx states, the spin is typically rather low $0.00-0.34$ e and often negative, reflecting that it is always a bridging ligand and that the net spin of the cluster is vanishing. For the IRed clusters, it has a higher spin, 0.35-0.53 e when the $\mathrm{Cu}_{\mathrm{T} 2}$ ligand is $\mathrm{H}_{2} \mathrm{O}$, and $0.10-0.21 e$ when it is $\mathrm{OH}^{-}$, i.e. similar or even larger than for the three $\mathrm{Cu}$ ions (up to $0.61 \mathrm{e}$ ). This mainly reflects that these complexes are not antiferromagnetically coupled. For the $\mathrm{NI}$ structures, the spin on $\mathrm{O}^{2-}$ is similar, $0.51-0.70$ e when the $\mathrm{Cu}_{T 2}$ ligand is $\mathrm{H}_{2} \mathrm{O}$ (but $0.33-0.49$ e for the two $\mathrm{O}^{2-}$ groups in $\mathrm{Nat}\left(\mathrm{H}_{2} \mathrm{O}, \mathrm{O}, \mathrm{O}\right)$ ), and $0.17-0.31 e$ when it is $\mathrm{OH}^{-}$, reflecting that these complexes are antiferromagnetically coupled but have a single unpaired electron.

Hydroxide ligands also have a varying spin. For most states, it is rather low, $0.00-0.25$ e. However, for three complexes with two $\mathrm{OH}^{-}$ions, $\mathrm{Ox}(\mathrm{OH}, \mathrm{OH})$ and $\mathrm{IOx}(\mathrm{OH}, \mathrm{OH})$, it is much higher, $0.36-0.43 e$, on the $\mathrm{Cu}_{T 2}$ ligand. It is also high on the $\mathrm{Cu}_{\mathrm{T} 2}$ ligand in the $\operatorname{IRed}\left(\mathrm{OH}, \mathrm{H}_{2} \mathrm{O}\right)$ and $\mathrm{PI}\left(\mathrm{OH}, \mathrm{HO}_{2}\right)$ complexes, 0.26-0.39 e.

\section{Geometries}

$\mathrm{Cu}$-ligand distances of all optimised structures are collected in Table S4. The $\mathrm{Cu}_{\mathrm{T} 1}$ site consists of a $\mathrm{Cu}$ ion bound to one Cys, one Met, and two His residues. When it is reduced, all $\mathrm{Cu}-$ ligand distances are elongated. The bond to Cys-500 increases from 2.18-2.20 to 2.22-2.23 $\AA$, with a variation of only $0.01 \AA$ over the 52 studied TNC states. The bonds to the two His residues increase from $1.98-2.00 \AA$ to $2.00-2.02 \AA$ for His-505 but to 2.03-2.07 $\AA$ for His-443. The former bond is $0.01-0.02 \AA$ longer in the optimisations with the neutralised protein, whereas the latter 
bond is shorter by a similar amount. Finally, the bond to Met-510 is appreciably weaker and it shows a larger variation (2.93-3.36 $\AA$ ), but it always increases by $0.11-0.22 \AA$ when the site is reduced.

The $\mathrm{Cu}-\mathrm{Cu}$ distances in the TNC primarily depend on the nature of the central and bridging ligands. In particular, a central $\mathrm{O}^{2-}$ ligand always gives rise to short $\mathrm{Cu}-\mathrm{Cu}$ distances (average distance $<3.45 \AA$ ), whereas all other states have longer $\mathrm{Cu}-\mathrm{Cu}$ distances. The oxidation state and the bridging ligand also has some influence, but in a less systematic manner. For example, shortest $\mathrm{Cu}-\mathrm{Cu}$ distances are observed for the $\mathrm{IRed}\left(\mathrm{H}_{2} \mathrm{O}, \mathrm{OH}, \mathrm{O}\right), \operatorname{IOx}\left(\mathrm{H}_{2} \mathrm{O}, \mathrm{O}, \mathrm{O}\right)$, and $\operatorname{Red}\left(\mathrm{H}_{2} \mathrm{O}, \mathrm{O}\right)$ states (average $\mathrm{Cu}-\mathrm{Cu}$ distances of $2.84,2.90$, and $2.97 \AA$, respectively), whereas the other states with a central $\mathrm{O}^{2-}$ ligand have average $\mathrm{Cu}-\mathrm{Cu}$ distance between 3.13 and $3.45 \AA$. States with other ligands show less systematic trends, but states without any central or bridging ligands give the longest $\mathrm{Cu}-\mathrm{Cu}$ distances $(4.54-4.72 \AA)$, followed by complexes with only a bridging water molecule (4.38-4.51 $\AA$ ). States with a $\mathrm{HO}_{2}^{-}$ligand also give longer average $\mathrm{Cu}-\mathrm{Cu}$ bonds (4.07$4.40 \AA$ ) than states with $\mathrm{a} \mathrm{O}_{2}{ }^{2-}$ ligand $(3.92-4.11 \AA$ ).

The $\mathrm{Cu}_{\mathrm{T} 2}$ ion binds to two His residues with distances of 1.86-2.22 $\AA$. The longer distances $(>2.0 \AA)$ are observed only for the $\operatorname{IOx}(\mathrm{OH}, \mathrm{OH}, \mathrm{O})$, IRed $\left(\mathrm{H}_{2} \mathrm{O}, \mathrm{OH}, \mathrm{O}\right)$, and $\operatorname{Red}\left(\mathrm{H}_{2} \mathrm{O}, \mathrm{O}\right)$ states. If the $\mathrm{Cu}_{\mathrm{T} 2}$ ligand is $\mathrm{OH}^{-}$, it binds at a distance of $1.85-1.93 \AA$ in most cases, except in the IOx/IRed $(\mathrm{OH}, \mathrm{O})$ and $\mathrm{NI}\left(\mathrm{OH} /(\mathrm{H}) \mathrm{O}_{2}\right)$ states, in which it is 1.95-2.02 $\AA$. If it is instead $\mathrm{H}_{2} \mathrm{O}$, it binds at a distance that increases from $\sim 2.12 \AA$ for the Ox states to $\sim 2.35 \AA$ for the Red states. If there is a central ligand, or even a bridging $\mathrm{Cu}_{\mathrm{T} 3}$ ligand, the distance can increase even more, especially for the IRed and Red states, up to $4.00 \AA$ for $\operatorname{Red}\left(\mathrm{H}_{2} \mathrm{O}, \mathrm{O}\right)$. A central $\mathrm{O}^{2-}$ ligand always coordinate also to the $\mathrm{Cu}_{\mathrm{T} 2}$ ion at a distance of 1.87-2.03 $\AA$. A central $\mathrm{OH}^{-}$ion binds at a similar distance (1.92$2.03 \AA$ ).

A central $(\mathrm{H}) \mathrm{O}_{2}$ ligand is normally close to the $\mathrm{Cu}_{\mathrm{T} 2}$ ion $2.08-2.35 \AA$, except in the $\mathrm{PI}\left(\mathrm{H}_{2} \mathrm{O}, \mathrm{HO}_{2}\right)$ state (and also in the $\mathrm{PI}\left(\mathrm{OH}, \mathrm{HO}_{2}\right)$ and $\mathrm{NI}\left(\mathrm{H}_{2} \mathrm{O}, \mathrm{HO}_{2}\right)$ with the neutralised protein), up to $3.31 \AA$. The distance is often longer in the $\mathrm{PI}$ than the $\mathrm{NI}$ states, and longer for $\mathrm{HO}_{2}^{-}$than for $\mathrm{O}_{2}{ }^{2-}$. The second $\mathrm{O}$ atom is further away from the $\mathrm{Cu}_{\mathrm{T} 2}$ ion $(2.92 \AA$ or larger), owing to the diagonal binding of the peroxide. Thus, most $\mathrm{NI}$ ' complexes have a significant $\mathrm{Cu}_{\mathrm{T}_{2}}-\mathrm{O}$ interaction with the (hydro)peroxide ligand in contrast to what was reported by Solomon and coworkers. It should be noted that for each complex, many different structures can be found, often with quite different $\mathrm{Cu}-\mathrm{O}$ bond lengths (and of course also with the diagonal (hydro)peroxide directed either towards the first or the second $\mathrm{Cu}_{\mathrm{T} 3}$ ion). These structures are typically close in energy (within $\sim 10$ $\mathrm{kJ} / \mathrm{mol}$ ). We have spent quite some effort to obtain the lowest energy structure for each complex (presented in the Tables), although this selection does not significantly affect the reported energies.

The $\mathrm{Cu}-\mathrm{N}$ distances of the two $\mathrm{Cu}_{\text {тз }}$ ions are typically $1.94-2.15 \AA$, i.e. somewhat longer than for the $\mathrm{Cu}_{T_{2}}$ ion, which reflects the higher coordination number of the $\mathrm{Cu}_{T_{3}}$ ions. The distance for His-499 is longer than the other five distances $(>1.99 \AA)$. Quite frequently longer distances are encountered when there is a central $\mathrm{O}^{2-}$ or $\mathrm{OH}^{-}$ion. In the $\mathrm{IOx} / \mathrm{IRed}\left(\mathrm{OH}, \mathrm{H}_{2} \mathrm{O}, \mathrm{O}\right)$ states, one of the His ligands has dissociated and instead forms a hydrogen bond to the $\mathrm{Cu}_{\mathrm{T} 3}$ water ligand (which is not bridging).

A central $\mathrm{O}^{2-}$ ion typically binds with nearly symmetric $\mathrm{Cu}_{\mathrm{T} 3}$ distances of $1.87-1.99 \AA$. However, the presence of another bridging $\mathrm{Cu}_{\mathrm{T}}$ ligand often makes the distances longer (up to $2.08 \AA$ ) and less symmetric.

Eight states have a central $\mathrm{OH}^{-}$ion. Those with a bridging $\mathrm{OH}^{-}$ion have quite symmetric distances to this ion (1.93-2.07 $\AA$ ), whereas the distances to the central $\mathrm{OH}^{-}$ion are less symmetric, 1.92-2.11 and 2.28-3.10 $\AA$ (depending on the direction of the proton). However, the two complexes with a bridging water molecule are much more distorted because one of the protons on the water molecule does not have any natural hydrogen-bond partner. Consequently, there is one short and one long $\mathrm{Cu}-\mathrm{O}$ bond for both the $\mathrm{OH}^{-}$ion $(1.97-2.09$ and 3.25-3.32 $\AA$ ) and the water molecule (2.04-2.14 and 2.99-3.18 $\AA$ ).

A $(\mathrm{H}) \mathrm{O}_{2}$ ligand binds in a diagonal fashion with one short and one long bond to each $\mathrm{Cu}_{\mathrm{T3}}$ ion. The former bond is slightly shorter for $\mathrm{O}_{2}{ }^{2-}(1.93-2.06 \AA)$ than for $\mathrm{HO}_{2}(1.99-2.12 \AA)$, but there is no consistent difference between the $\mathrm{PI}$ and $\mathrm{NI}$ ' oxidation states. The longer bond is 2.62-3.22 $\AA$. In all cases, the O-O bond is intact, $1.32-1.50 \AA$. This is intermediate between the bond length 
of a free superoxide ion, calculated at the same level $\left(1.35 \AA\right.$ for $\mathrm{O}_{2}{ }^{-} ; 1.32 \AA$ for $\left.\mathrm{HO}_{2}\right)$ and a free peroxide ion (1.62 $\AA$ for $\mathrm{O}_{2}{ }^{2-} ; 1.53 \AA$ for $\mathrm{HO}_{2}$ ). The O-O bond length is $0.03-0.08 \AA$ longer for the $\mathrm{NI}$ ' states than for the PI states, indicating a stronger superoxide character in the latter cases (which is also supported by the spin densities). It is also $0.02-0.07 \AA$ longer for $\mathrm{HO}_{2}^{-}$than for $\mathrm{O}_{2}{ }^{2-}$ and it is $0.03-0.08 \AA$ longer if the $\mathrm{Cu}_{\mathrm{T} 2}$ ligand is a hydroxide than if it is water. Consequently, the $\mathrm{PI} / \mathrm{NI}^{\prime}\left(\mathrm{H}_{2} \mathrm{O}, \mathrm{O}_{2}\right)$ states have the shortest $\mathrm{O}-\mathrm{O}$ bond and the $\mathrm{PI} / \mathrm{NI}\left(\mathrm{OH}, \mathrm{HO}_{2}\right)$ states have the longest bond, whereas the $\mathrm{PI} / \mathrm{NI}\left(\mathrm{OH}, \mathrm{O}_{2}\right)$ and $\mathrm{PI} / \mathrm{NI}^{\prime}\left(\mathrm{H}_{2} \mathrm{O}, \mathrm{HO}_{2}\right)$ states have similar $\mathrm{O}-\mathrm{O}$ bond lengths.

A bridging $\mathrm{OH}^{-}$group binds with $\mathrm{Cu}-\mathrm{O}$ distances of 1.91-2.09 $\AA$ with an average difference between the two $\mathrm{Cu}$ ions of $0.05 \AA$ (the distorted $\operatorname{Red}(\mathrm{H} 2 \mathrm{O}, \mathrm{OH}, \mathrm{O})$ state has one $\mathrm{Cu}-\mathrm{O}$ distance of 2.10-2.17 $\AA$ ). A bridging water ligand has longer $\mathrm{Cu}-\mathrm{O}$ distances 2.04-2.77 $\AA$ and a larger asymmetry (in many cases with central ligands, the water molecules binds effectively only to one of the two $\mathrm{Cu}_{\mathrm{T} 3}$ ions). The bond lengths decrease when the oxidation state of the $\mathrm{Cu}$ ions increases.

A change in the protonation state of Asp-373 has a very small effect of the geometry of the TNC: All the $\mathrm{Cu}$-ligand distances change by less than $0.02 \AA$, showing that the geometry optimisations give stable results. Likewise, the $\mathrm{Cu}$-ligand distances of the TNC are not much influenced by the oxidation state of the CuT1 site, with differences typically below $0.05 \AA$.

\section{Redox potentials}

We have calculated redox potentials between 21 different states of the TNC. To make the calculations more stable, we do not calculate the redox potential of the TNC directly, but instead study the transfer of an electron from the $\mathrm{Cu}_{\mathrm{T} 1}$ site to the TNC. Thereby, the net charge of the total system does not change and long-range electrostatic effects are reduced. The absolute redox potential of the TNC can be estimated using the experimental redox potential of the $\mathrm{Cu}_{\mathrm{T} 1}$ site, 0.46 $\mathrm{V}$ at $\mathrm{pH} 7.0^{91}$ (throughout this article, all redox potentials are versus the standard hydrogen electrode).

The redox potentials of the various TNC states relative to the $\mathrm{Cu}_{\mathrm{T} 1}$ site, calculated with QTCP approach are listed in Table 1. It can be seen that the statistical precision of all calculated potentials is reasonable, $0.01-0.03 \mathrm{~V}(1-3 \mathrm{~kJ} / \mathrm{mol})$. A positive relative redox potential indicates that the TNC can be reduced by the $\mathrm{Cu}_{\mathrm{T} 1}$ site, i.e. that the forward reaction in the MCO reaction cycle is favourable. The results show that most of the reactions are predicted to be favourable in this direction. Moreover, the relative redox potential of the TNC decreases (becomes more negative) as the number of protons decrease, i.e. the net charge of the TNC decreases: The relative redox potential is positive for TNC states with a net charge of $+3,+4$, and $+5(0-1.4,1.6-2.5$, and $4.7 \mathrm{~V}$, respectively) whereas it is negative $(-0.4$ to $-1.5 \mathrm{~V})$ for states with a net charge of +2 . This is a combined effect of the electrostatic solvation energy, which always is negative, but decreasing with the charge (around $-7.4,-5.6,-3.8$, and $-2.1 \vee$ for TNC charges of $+5,+4,+3$, and +2 ) and the intrinsic QM redox potential, which is always positive, but decreasing even more with the net charge.

\section{Acidity constants}

We have also calculated acidity constants for 40 states of the TNC (and for the $\mathrm{Cu}_{\mathrm{T} 1}$ site in both the reduced and oxidised states). To make the results more stable by conserving the total charge of the system, the proton was moved to a solvent-exposed carboxylate group on the other side of the protein, rather than simply being deleted. After some testing (discussed in the $\mathrm{SI}$ ), we selected Asp-373 as the proton acceptor, because it gave results close to the average among the tested groups and it does not form any hydrogen bond with other protein groups, neither in the protonated nor the deprotonated state. Since the $\mathrm{p} K_{\mathrm{a}}$ value of solvent-exposed carboxylate groups on the surface of a protein seldom change by more than one unit, ${ }^{34,44}$ we can obtain the acidity constant of the TNC by using the intrinsic $p K_{a}$ of an Asp group, $\sim 4.0 .^{34,70}$ Consequently, protonation of the TNC is predicted to be favourable at $\mathrm{pH} 7$ if the calculated relative $\mathrm{p} K_{\mathrm{a}}$ value in Table 2 is larger than 3.

As shown in Table 2, it can be seen that the results predict that the $\mathrm{Ox}(\mathrm{OH}, \mathrm{OH})$ state is more stable than the $\mathrm{Ox}\left(\mathrm{H}_{2} \mathrm{O}, \mathrm{OH}\right)$ state throughout the physiological $\mathrm{pH}$ range, in accordance with 
experimental observations, ${ }^{10,92}$ giving some credence to the calculations. As expected, the relative $\mathrm{pK}_{\mathrm{a}}$ value always increases (becomes more positive) if a TNC site with the same ligands is reduced by one electron (by $10-40 \mathrm{pK}_{\mathrm{a}}$ units; average 30 ) and it decreases as the number of protons (and therefore the net charge) of the TNC in the same oxidation state is increased ( $\mathrm{pK}$ values of -59 to $-63,-24$ to $-46,-25$ to 19 , and $8-38$ for TNC sites with a net charge of $+5,+4$, +3 , and +2 , respectively). Consequently, the calculations always predict that the TNC states with a net charge of +2 or +3 are most stable.

The statistical precision of the calculated results is reasonable, 0.6-0.9 $\mathrm{p} K_{\mathrm{a}}$ units, except for the three reactions involving the $\operatorname{IOx}\left(\mathrm{H}_{2} \mathrm{O}, \mathrm{H}_{2} \mathrm{O}, \mathrm{O}\right)$ state (1-3 $\mathrm{p} K_{\mathrm{a}}$ units) and also one reaction involving the corresponding $\operatorname{IRed}\left(\mathrm{H}_{2} \mathrm{O}, \mathrm{H}_{2} \mathrm{O}, \mathrm{O}\right)$ state $(0.9-1.1 \mathrm{pK}$ a units), which come from steric clashes in one of the coordinate perturbations.

\section{Isomerisation free energies}

We have also studied 19 isomerisation reactions between states that differ in the position of a single proton (in all cases with the $\mathrm{Cu}_{\mathrm{T} 1}$ site in both the reduced and oxidised states and using a neutralised protein). The calculated isomerisation free energies are collected in Table 3 , using the convention that a negative sign indicates that the product is more stable. The precision is 1-3 $\mathrm{kJ} / \mathrm{mol}$, again except for four reactions involving the IOx and IRed $\left(\mathrm{H}_{2} \mathrm{O}, \mathrm{H}_{2} \mathrm{O}, \mathrm{O}\right)$ states.

The results show that it is more favourable to protonate the $\mathrm{Cu}_{\mathrm{T} 2}$ ligand than a peroxide ligand (i.e. $\left(\mathrm{H}_{2} \mathrm{O}, \mathrm{O}_{2}\right)$ is more favourable than $\left.\left(\mathrm{OH}, \mathrm{HO}_{2}\right)\right)$. States with two $\mathrm{O}^{2-}$ ions $(X, \mathrm{O}, \mathrm{O})$ are not favourable, but states with two $\mathrm{OH}^{-}$ions $(X, \mathrm{OH}, \mathrm{OH})$ are energetically preferred over $\left(X, \mathrm{H}_{2} \mathrm{O}, \mathrm{O}\right)$ states, independent on the oxidation state. On the other hand, the proton transfer from a $\mathrm{Cu}_{\mathrm{T} 2}$ water molecule to a central $\mathrm{O}^{2-}$ ion (i.e. from $\left(\mathrm{H}_{2} \mathrm{O}, X, \mathrm{O}\right)$ to $\left.(\mathrm{OH}, X, \mathrm{OH})\right)$ can be either favourable or unfavourable, depending on the oxidation state of the TNC and the presence of a bridging $\mathrm{Cu}_{T 3}$ ligand.

We have also studied the reaction free energies for the cleavage of the $\mathrm{O}-\mathrm{O}$ bond in three $\mathrm{NI}$ states. These results are also included at the end of Table 3 and they show that the reaction is slightly uphill if the peroxide is not protonated, whereas it is strongly downhill if it is protonated. The reaction is further favoured if the $\mathrm{Cu}_{\mathrm{T} 2}$ ligand is $\mathrm{O} \mathrm{OH}^{-}$ion. These results are similar to our previous QM/MM results of the same reactions, ${ }^{26}$ although there are differences of $15-34 \mathrm{~kJ} / \mathrm{mol}$ in the energies, owing to differences in the methods and the basis sets (the DFT-D3 dispersion correction, which was not included in the previous study, contributes by $23-25 \mathrm{~kJ} / \mathrm{mol}$ ), as well as the rather large uncertainty of the QTCP results, $5-10 \mathrm{~kJ} / \mathrm{mol}$.

Yoon and Solomon have studied the $\mathrm{O}-\mathrm{O}$ bond cleavage with QM-cluster calculations. ${ }^{20}$ They started from a NI' $\left(\mathrm{H}_{2} \mathrm{O}, \mathrm{O}_{2}\right)$ state, but with Glu-506 protonated and moved so that it formed a direct hydrogen bond to the lower $\mathrm{O}_{2}$ atom, and also with several bond lengths, angles, and dihedrals fixed to the values in the crystal structure to avoid artificial changes in the structures. They observed that the proton is transferred to the peroxide ion, either before or during the reaction and obtain a much more exergonic reaction free energy $(204 \mathrm{~kJ} / \mathrm{mol})$ than in any of our calculations (although we do not study exactly the same reactions). They assigned the different modes of proton transfer to the experimental observation of different kinetic isotope effects at low and high $\mathrm{pH}$, but this is unlikely, as a change of the external $\mathrm{pH}$ would change the total number of protons in the modelled reaction (e.g. by removing the extra proton on the Glu-506 model at high $\mathrm{pH})$. They reported that the state in which the proton has moved from Glu-506 to $\mathrm{O}_{2}$ is $9 \mathrm{~kJ} / \mathrm{mol}$ lower than the other state and that the barrier for this proton transfer is low. This means that the state with Glu-506 protonated would instantly be converted to the other state and should not have any influence on the reaction rate, independent of the $\mathrm{pH}$. In addition, they reported an activation barrier of only $\sim 12 \mathrm{~kJ} / \mathrm{mol}$, which would correspond to a rate of $\sim 10^{10} \mathrm{~s}^{-1}$, (using a standard prefactor in the Arrhenius equation, $6 \cdot 10^{12} \mathrm{~s}^{-1} 93$ ), much larger than the observed rate of $>350 \mathrm{~s}^{-1}$. We strongly believe that our calculations including the full protein without any constraints should be more realistic. 


\section{Binding free energies}

Our results also let us to estimate the binding free energy of $\mathrm{O}_{2}$ to the Red complexes, forming the $\mathrm{PI}$, and the dissociation of water from the various IOx, IRed, and Red complexes. These free energies are more approximate than the other energies in this article, because they are based on the QM/MM-PBSA calculations (because it is difficult to estimate binding free energies with the QTCP approach). Moreover, they include a contribution from the dissociated molecule that can be estimated in several different ways. Fortunately, it is only a constant factor that contributes equally to all reactions with the same binding molecule. For simplicity, we decided to estimate this contribution from a B3LYP/def2-TZVPD calculation in the COSMO continuum solvent with a dielectric constant of 80 (water). The dissociated species is also favoured by an entropy term from the enhanced translational and rotational freedom. The size of this term has been much discussed ${ }^{94-96}$ and we have modelled it by simply adding $30 \mathrm{~kJ} / \mathrm{mol}$ to the dissociated species.

The resulting free energies are shown in Table 4. It can be seen that the dissociation of $\mathrm{H}_{2} \mathrm{O}$ from all complexes is favourable (we have only studied the dissociation of a water molecule from a bridging position between the two $\mathrm{Cu}_{\mathrm{T} 3}$ ions). The reaction seems to be more favourable for the IOx and IRed complexes than for the Red complexes.

On the other hand, binding of $\mathrm{O}_{2}$ is favourable for the $\operatorname{Red}(\mathrm{OH},-)$ complex, but not for the $\operatorname{Red}\left(\mathrm{H}_{2} \mathrm{O},-\right)$ complex. However, these free energies are uncertain, because there is a very large difference between the results obtained by the PBE and the B3LYP methods: With PBE, both binding reactions are favourable by $49-91 \mathrm{~kJ} / \mathrm{mol}$. The reason for this is the change in the oxidation state of two copper ions and the $\mathrm{O}_{2}$ ligand during binding: Large differences between pure (e.g. PBE) and hybrid DFT functionals (e.g. B3LYP) are often observed when the oxidation state of metal complexes is changed. ${ }^{32,97,98}$ For the dissociation of $\mathrm{H}_{2} \mathrm{O}$ (which does not involve any change in the oxidation state of the TNC), the results with the two DFT functionals agree within $17 \mathrm{~kJ} / \mathrm{mol}$, except for two complexes $(23-31 \mathrm{~kJ} / \mathrm{mol})$.

\section{Communication between redox sites}

The present calculations allow us to study how the two copper sites communicates, i.e. how changes in the redox or protonation state affects the redox potential and acidity of the other site. From Table 2, it can be seen that the acidity constants of the TNC in general decrease by $\sim 3$ $\mathrm{pK}_{\mathrm{a}}$ units when the $\mathrm{Cu}_{\mathrm{T} 1}$ site is oxidised, reflecting that the $\mathrm{Cu}_{\mathrm{T} 1}$ site is much closer to the TNC ( $\sim 12.5 \AA \mathrm{Cu}-\mathrm{Cu}$ distance) than to Asp-373 ( 24 $\AA \mathrm{Cu}-\mathrm{CG}$ distance; the TNC is always positively charged and this charge is one unit higher in the protonated state than in the deprotonated state; the $\mathrm{Cu}_{\mathrm{T} 1}$ site is neutral in the reduced state but has a single positive charge in the oxidised state).

For the isomerisation and O-O cleavage reactions in Table 3, it can be seen that the effect of the $\mathrm{Cu}_{\mathrm{T} 1}$ oxidation state is more varying (because the reactions conserve the net charge of the TNC), so it is no longer obvious which state will be favoured. For most reactions, the effect is restricted, $0-9 \mathrm{~kJ} / \mathrm{mol}$, but for seven reactions, it is larger, up to $28 \mathrm{~kJ} / \mathrm{mol}$, although this mainly reflects the larger computational uncertainty of these energies (especially those involving the IOx and IRed $\left(\mathrm{H}_{2} \mathrm{O}, \mathrm{H}_{2} \mathrm{O}, \mathrm{O}\right)$ states.

Further information about the communication between the two $\mathrm{Cu}$ sites in the MCOs can be obtained by using the QM/MM-PB(GB)SA results to calculate absolute reduction potentials for either that $\mathrm{Cu}_{\mathrm{T} 1}$ site or for the TNC in the various states of the other site. Concentrating first on the $\mathrm{Cu}_{\mathrm{T} 1}$ site, Figure 4 shows how the reduction potential of the $\mathrm{Cu}_{\mathrm{T} 1}$ site varies when the oxidation and protonation state of the TNC is varied. It can be seen that the $\mathrm{Cu}_{\mathrm{T} 1}$ potentials are predicted to vary by over $0.4 \mathrm{~V}$, depending on the state of the TNC. However, this is primarily a charge effect, reflecting the repulsion between the oxidised state of the $\mathrm{Cu}_{\mathrm{T} 1}$ site (with a net charge of $+1 \mathrm{e}$ ) and the TNC (with a net charge of 1-5 e), giving the highest potentials $\left(\mathrm{Cu}_{\mathrm{T} 1}\right.$ reduced state most stable) for the highest charge. For the TNC states with a net charge of 2-3 (which in general seem to be preferred), the variation is only $0.18 \mathrm{~V}(0.35-0.53 \mathrm{~V})$. Still, the results clearly show that the state of the TNC need to be specified if it should be meaningful to discuss the redox potential of the $\mathrm{Cu}_{\mathrm{T} 1}$ site to an accuracy better than $0.2 \mathrm{~V}$ and that the $\mathrm{Cu}_{\mathrm{T} 1}$ potential obtained for the resting Ox state probably is not representative for turn-over conditions. 
Conversely, our calculations show that the $\mathrm{Cu}_{T 1}$ site has a somewhat smaller effect on the redox potential of the TNC. An oxidised $\mathrm{Cu}_{\mathrm{T} 1}$ site gives a $0.06-0.13 \mathrm{~V}$ higher potential $(0.08 \mathrm{~V}$ on average) than the reduced $\mathrm{Cu}_{\mathrm{T} 1}$ site (results in Table $\mathrm{S} 4$ in the $\mathrm{SI}$ ). The reason is again the electrostatic interaction that is more unfavourable for the oxidised $\mathrm{Cu}_{\mathrm{T} 1}$ site (net charge +1 ) and the oxidised TNC, which always has one unit more positive charge than the reduced TNC.

\section{Implication on reaction mechanism}

We can now use these results to study the full reaction mechanisms of the MCOs. We start from the Red state with no bridging ligand. It can have either a water or $\mathrm{OH}^{-}$ion as the $\mathrm{Cu}_{T 2}$ ligand, $\operatorname{Red}\left(\mathrm{H}_{2} \mathrm{O},-\right)$ or $\operatorname{Red}(\mathrm{OH},-)$. The results in Table 2 indicate that these two states are close in energy at $\mathrm{pH}$ 7. They should bind $\mathrm{O}_{2}$ and according to Table 4, this reaction is possible only for $\operatorname{Red}(\mathrm{OH},-)$. However, this suggestion is uncertain because the PBE calculations indicate that the $\mathrm{O}_{2}$ binding to $\operatorname{Red}\left(\mathrm{H}_{2} \mathrm{O},-\right)$ is also favourable by $49 \mathrm{~kJ} / \mathrm{mol}$.

When $\mathrm{O}_{2}$ is bound, a $\mathrm{PI}$ state is formed, either $\mathrm{PI}\left(\mathrm{H}_{2} \mathrm{O}, \mathrm{O}_{2}\right)$ or $\mathrm{PI}\left(\mathrm{OH}, \mathrm{O}_{2}\right)$. The results in Table 2 indicate that the $\mathrm{PI}\left(\mathrm{OH}, \mathrm{O}_{2}\right)$ state is most stable at $\mathrm{pH}$ 7. Moreover, it can be seen that the peroxide ion is unlikely to be protonated, in accordance with experimental studies. ${ }^{10}$ From Table 1 , it can be seen that only the $\mathrm{PI}\left(\mathrm{OH}, \mathrm{O}_{2}\right)$ state is unlikely to be reduced by the $\mathrm{Cu}_{\mathrm{T} 1}$ site. This is a general problem for all the considered states: The relative acid constants indicate that the states with a net charge of the TNC of +2 or +3 (i.e. quite deprotonated) are most stable, whereas the relative redox potentials indicate that these states are unlikely to be reduced, but the more protonated states are readily reduced by $\mathrm{Cu}_{T 1}$. A possible solution to this dilemma is that a proton transfer accompanies the electron transfer, i.e. a coupled electron-proton transfer (EPT), as has also been suggested by Solomon and coworkers for some states ${ }^{30}$ Therefore, we have in Table 5 combined the results from Tables 1 and 2 . The electron is taken from $\mathrm{Cu}_{\mathrm{T} 1}$ and the proton from Asp-373 and the results are expressed in $\mathrm{p} K_{\mathrm{a}}$ units, so that a forward electron and proton transfer is predicted to be favourable at $\mathrm{pH} 7$ if the result is more positive than 3 (as in Table 2). These results are somewhat more uncertain than the results in Table 1 and 2, because they are obtained from two different QTCP calculations, using different optimised structures. It can be seen from Table 5 that the EPT is still slightly unfavourable (by $1-3 p K_{a}$ units or $9-17 \mathrm{~kJ} / \mathrm{mol}$ ), which is within the error limits of the present method (we seem underestimate the stability of the reduced TNC by $\sim 25 \mathrm{~kJ} / \mathrm{mol}$, as we will see also for the other reactions).

The EPT from $\mathrm{PI}\left(\mathrm{OH}, \mathrm{O}_{2}\right)$ gives either the $\mathrm{NI}^{\prime}\left(\mathrm{H}_{2} \mathrm{O}, \mathrm{O}_{2}\right)$ or $\mathrm{NI}\left(\mathrm{OH}, \mathrm{HO}_{2}\right)$ states, which are the most stable protonation states according to Table 2. However, the isomerisation energies in Table 3 indicate that the $\mathrm{NI}^{\prime}\left(\mathrm{H}_{2} \mathrm{O}, \mathrm{O}_{2}\right)$ state is the most stable $\mathrm{Nl}$ state, by $30-34 \mathrm{~kJ} / \mathrm{mol}$. This is somewhat unexpected, because the cleavage of the $\mathrm{O}-\mathrm{O}$ bond in this state is slightly uphill (by 23-25 kJ/mol), whereas it is strongly downhill for the $\mathrm{Nl}^{\prime}\left(\mathrm{OH}, \mathrm{HO}_{2}\right)$. The favourable $\mathrm{O}-\mathrm{O}$ cleavage in $\mathrm{NI}^{\prime}\left(\mathrm{OH}, \mathrm{HO}_{2}\right)$ gives rise to $\mathrm{NI}(\mathrm{OH}, \mathrm{OH}, \mathrm{O})$, which is the most stable $\mathrm{NI}$ state. Alternatively, $\mathrm{NI}^{\prime}\left(\mathrm{H}_{2} \mathrm{O}, \mathrm{O}_{2}\right)$ may give rise to the $\mathrm{NI}\left(\mathrm{H}_{2} \mathrm{O}, \mathrm{O}, \mathrm{O}\right)$ state, which is predicted to isomerise to the $\mathrm{NI}(\mathrm{OH}, \mathrm{OH}, \mathrm{O})$ state, which is $63-84 \mathrm{~kJ} / \mathrm{mol}$ more stable. This strongly favourable isomerisation may drive a slightly uphill $\mathrm{O}-\mathrm{O}$ bond cleavage.

Again, $\mathrm{NI}(\mathrm{OH}, \mathrm{OH}, \mathrm{O})$ cannot be directly reduced by the $\mathrm{Cu}_{\mathrm{T} 1}$ site, but the EPT to $\mathrm{IOx}(\mathrm{OH}, \mathrm{OH}, \mathrm{OH})$ is only slightly unfavourable (by $4 \mathrm{pK}$ units or $25 \mathrm{~kJ} / \mathrm{mol})$. The protonation and isomerisation energies in Tables 2 and 3 show that $\mathrm{IOx}(\mathrm{OH}, \mathrm{OH}, \mathrm{OH})$ is the most stable $\mathrm{IOx}$ state.

The direct reduction of $\mathrm{IOx}(\mathrm{OH}, \mathrm{OH}, \mathrm{OH})$ is unfavourable, but the EPT to IRed $\left(\mathrm{OH}, \mathrm{H}_{2} \mathrm{O}, \mathrm{OH}\right)$ is favoured by $4 \mathrm{pKa}$ units $(24 \mathrm{~kJ} / \mathrm{mol})$. From the latter state, a water molecule can readily dissociate (Table 4), giving rise to the $\mathrm{IRed}(\mathrm{OH}, \mathrm{OH})$ state.

Again, the reduction of the $\operatorname{IRed}(\mathrm{OH}, \mathrm{OH})$ state is unfavourable, but the EPT to $\operatorname{Red}\left(\mathrm{H}_{2} \mathrm{O}, \mathrm{OH}\right)$ or $\operatorname{Red}\left(\mathrm{OH}, \mathrm{H}_{2} \mathrm{O}\right)$ is favourable or nearly favourable at $\mathrm{pH}$. The latter state is predicted to lose the water to form the $\operatorname{Red}(\mathrm{OH},-)$ state. $I \operatorname{Red}\left(\mathrm{H}_{2} \mathrm{O}, \mathrm{OH}\right)$ seems to be the more stable, but it needs to be protonated to $\operatorname{Red}\left(\mathrm{H}_{2} \mathrm{O}, \mathrm{H}_{2} \mathrm{O}\right)$ before a water is predicted to dissociate (which could drive the protonation). Thereby, we are back to the reduced state without any bridging ligand, which is the starting point of our catalytic cycle. Structures of the key intermediates in this suggested mechanism are shown in Figure 5. 


\section{Conclusions}

In this study we have used advanced QM/MM-FEP methods to study the complete reaction mechanism of the multicopper oxidases, including the re-reduction of the TNC after the formation of the NI. This mechanism involves four reduction and protonation reactions, which are quite challenging to study with theoretical methods, owing to the change in the net charge of the protein and the correlation energy. We have reduced these problems by studying only the internal electron transfer between the $\mathrm{Cu}_{\mathrm{T} 1}$ ion and the TNC or the proton transfer between the TNC and a carboxylate group on the protein surface, thereby keeping the net charge of the protein constant. Moreover, we have tested to neutralise all charged groups on the surface of the protein, which are known not to affect the reduction potentials or $\mathrm{p} K_{\mathrm{a}}$ values, thereby making the calculated energies more stable. Finally, we have used several different methods, employing both explicit water simulations and continuum solvation methods, to ensure that the calculated energies are stable and consistent. Fortunately, the values of most of the calculated energies are quite large so that we can predict the direction of most of the reactions even if the accuracy of the calculations in not better than $\sim 30 \mathrm{~kJ} / \mathrm{mol}$.

Our calculations give rise to a tentative reaction mechanism, depicted in Figure 5 . It can be seen that the calculations predict that the net charge of the TNC (i.e. the copper ions and their direct ligands) is 1-3 e throughout the whole catalytic cycle (and the most stable state at each oxidation-state has a charge of 2 or $3 e$ ), as could be expected from the presence of two conserved neutralising carboxylate groups close to TNC in the protein, Asp-112 and Glu-506. The TNC is predicted to be reduced by the CuT1 site in the $\mathrm{PI}\left(\mathrm{OH}, \mathrm{O}_{2}\right), \mathrm{NI}(\mathrm{OH}, \mathrm{OH}, \mathrm{O}), \mathrm{IOx}(\mathrm{OH}, \mathrm{OH}, \mathrm{OH})$, and IRed $(\mathrm{OH}, \mathrm{OH})$ states by coupled electron-proton transfer reaction. Moreover, water molecules are predicted to dissociate rather late in the mechanism, probably from the IRed $(\mathrm{OH}, \mathrm{H} 2 \mathrm{O}, \mathrm{OH})$ and $\operatorname{Red}\left(\mathrm{OH}, \mathrm{H}_{2} \mathrm{O}\right)$ or $\operatorname{Red}\left(\mathrm{H}_{2} \mathrm{O}, \mathrm{H}_{2} \mathrm{O}\right)$ states. However, it is less clear whether the $\mathrm{O}-\mathrm{O}$ cleavage takes place for the $\mathrm{NI}^{\prime}\left(\mathrm{H}_{2} \mathrm{O}, \mathrm{O}_{2}\right)$ state (for which the reaction may be slightly uphill) or in the $\mathrm{NI}\left(\mathrm{OH}, \mathrm{HO}_{2}\right)$ state, for which the reaction is strongly favourable.

In a recent QM-cluster study, Solomon and coworkers studied the re-reduction of $\mathrm{NI}$ to the Red state. ${ }^{30}$ They also used B3LYP calculations, but with smaller basis sets and treating the surrounding protein only as a continuum solvent with a dielectric constant of 4 , thereby being forced to fix two atoms in each imidazole ligand. They consider only the isolated TNC and in several cases show protons on $\mathrm{OH}^{-}$and $\mathrm{H}_{2} \mathrm{O}$ groups pointing in unexpected directions (e.g. towards the $\mathrm{Cu}$ ions). Our QM/MM-FEP calculations should give a much more detailed account of the surrounding protein and dynamic effects. Solomon et al. considered only water as the $\mathrm{Cu}_{\mathrm{T} 2}$ ligand, whereas our results (cf. Table 2) indicate that most states are more stable with $\mathrm{OH}^{-}$as the $\mathrm{Cu}_{\mathrm{T} 2}$ ligand, giving a less positive net charge of the TNC, and therefore much less favourable electron-transfer energies. Moreover, they suggest that both water molecules dissociate in the Red state (actually the second water molecule never dissociates in their calculations, in contrast to the crystal structure of the Red state ${ }^{14}$ ), whereas the first water ligand dissociates in the IRed state in our mechanism. In fact, our results indicate that $I R e d\left(\mathrm{H}_{2} \mathrm{O}, \mathrm{H}_{2} \mathrm{O}, \mathrm{OH}\right)$, involved in their mechanism has the most favourable water dissociation energy of all studied complexes in Table 4. This seems to be connected with a desire to reproduce kinetically estimated driving forces of the three electron-transfer reactions between $\mathrm{NI}$ and $\operatorname{Red}\left(\mathrm{IRed}\left(\mathrm{H}_{2} \mathrm{O}, \mathrm{OH}\right)\right.$ would give a too low driving force for the last electron transfer, as in our calculations). We are not fully convinced that the driving forces suggested in ref. 30 are the only that can fit the kinetic data (a complicated mechanism with at least 14 kinetic parameters) nor that the QM-cluster or QTCP calculations are accurate enough to allow a quantitative comparison with the kinetic data. Still, our mechanisms agree that the most stable $\mathrm{NI}$ state is $\mathrm{NI}(X, \mathrm{OH}, \mathrm{O})$ (where $X$ is $\mathrm{H}_{2} \mathrm{O}$ in their calculations and $\mathrm{OH}^{-}$in our calculations), that the most stable $\mathrm{IOx}$ state is $\mathrm{IOx}(X, \mathrm{OH}, \mathrm{OH})$, and that the $\mathrm{IRed}\left(X, \mathrm{H}_{2} \mathrm{O}, \mathrm{OH}\right)$ state is involved in the mechanism.

Our calculations show that there is a significant communication between the two Cu sites in the MCO, through the net charge ( +1 or 0 for the $\mathrm{Cu}_{T 1}$ site and $+1-3$ for the TNC): The redox potential of the $\mathrm{Cu}_{T 1}$ is predicted to vary by up to $0.18 \mathrm{~V}$ depending on the state of the TNC. Likewise, the oxidation state of $\mathrm{Cu}_{\mathrm{T} 1}$ site is predicted to affect the redox potential of the TNC by $\sim 0.08 \mathrm{~V}$ and modify acidity constants by $\sim 3 \mathrm{pK}$ anits. This shows that it is rather meaningless to 
discuss reduction potentials and acidity constants of one site without specifying the state of the other site.

In conclusion, we have shown how advanced multi-scale modelling can be used to gain atomistic information of the structures and energies of the various states in the reaction mechanism of the MCOs. We think that the presented methodology represents a robust computational treatment of challenging problems in the bioinorganic chemistry, establishing a link between computations and experimental data.

\section{Acknowledgements}

This investigation has been supported by grants from the Swedish research council (project 20145540), the Grant Agency of the Czech Republic (project 14-31419S), from the Crafoord foundation, and from COST through Action CM1305 (ECOSTBio). The computations were performed on computer resources provided by the Swedish National Infrastructure for Computing (SNIC) at Lunarc at Lund University.

\section{Supporting Information Available}

Test of various proton-accepting sites, influence of the basis sets on the calculated energies, spin states and geometries of the various states, and calculated absolute redox potentials. This information is available free of charge via the Internet at http://pubs.acs.org. 


\section{References}

[1] Solomon, E. I.; Heppner, D. E.; Johnston, E. M.; Ginsbach, J. W.; Cirera, J.; Qayyum, M.; Kieber-Emmons, M. T.; Kjaergaard, C. H.; Hadt, R. G.; Tian, L., Copper Active Sites in Biology. Chem. Rev. 2014, 114, 3659-3853.

[2] Claus, H., Laccases and Their Occurrence in Prokaryotes. Arch. Microbiol. 2003, 179, 145150.

[3] Quintanar, L.; Stoj, C.; Taylor, A. B.; Hart, P. J.; Kosman, D. J.; Solomon, E. I., Shall We Dance? How A Multicopper Oxidase Chooses its Electron Transfer Partner. Acc. Chem. Res. 2007, 40, 445-452.

[4] Giardina, P.; Faraco, V.; Pezzella, C.; Piscitelli, A.; Vanhulle, S.; Sannia, G., Laccases: A Never-ending Story. Cell. Mol. Life Sci. 2010, 67, 369-385.

[5] Cracknell, J. A.; Vincent, K. A.; Armstrong, F. A., Enzymes as Working or Inspirational Electrocatalysts for Fuel Cells and Electrolysis. Chem. Rev. 2008, 108, 2439-2461.

[6] Solomon, E. I.; Chen, P.; Metz, M.; Lee, S.-K.; Palmer, A. E., Oxygen Binding, Activation, and Reduction to Water by Copper Proteins. Angew. Chem. Int. Ed. 2001, 40, 4570-4590.

[7] Bento, I.; Martins, L. O.; Gato Lopes, G.; Armenia Carrondo, M.; Lindley, P. F., Dioxygen Reduction by Multi-Copper Oxidases; A Structural Perspective. Dalton. Trans. 2005, 3507-3513.

[8] Bento, I.; Carrondo, M. A.; Lindley, P., Reduction of Dioxygen by Enzymes Containing Copper. J. Biol. Inorg. Chem. 2006, 11, 539-547.

[9] Yoon, J.; Solomon, E. I., Electronic Structures of Exchange Coupled Trigonal Trimeric $\mathrm{Cu}$ (II) Complexes: Spin Frustration, Antisymmetric Exchange, Pseudo-A Terms, and Their Relation to $\mathrm{O}_{2}$ Activation in the Multicopper Oxidases. Coord. Chem. Rev. 2007, 251, 379-400.

[10] Solomon, E. I.; Augustine, A. J.; Yoon, J., $\mathrm{O}_{2}$ Reduction to $\mathrm{H}_{2} \mathrm{O}$ by the Multicopper Oxidases. Dalton. Trans. 2008, 3921-3932.

[11] Solomon, E. I.; Ginsbach, J. W.; Heppner, D. E.; Kieber-Emmons, M. T.; Kjaergaard, C. H.; Smeets, P. J.; Tian, L.; Woertink, J. S., Copper Dioxygen (bio)Inorganic Chemistry. Faraday. Discuss. 2011, 148, 11-39.

[12] Rulíšek, L.; Solomon, E. I.; Ryde, U., A Combined Quantum and Molecular Mechanical Study of the $\mathrm{O}_{2}$ Reductive Cleavage in the Catalytic Cycle of Multicopper Oxidases. Inorg. Chem. 2005, 44, 5612-5628.

[13] Rulíšek, L.; Ryde, U., Theoretical Studies of the Active-Site Structure, Spectroscopic and Thermodynamic Properties, and Reaction Mechanism of Multicopper Oxidases. Coord. Chem. Rev. 2013, 257, 445-458.

[14] Messerschmidt, A.; Ladenstein, R.; Huber, R.; Bolognesi, M.; Avigliano, L.; Petruzzelli, R.; Rossi, A.; Finazzi-Agró, A., Refined Crystal Structure of Ascorbate Oxidase at 1.9 Å Resolution. J. Mol. Biol. 1992, 224, 179-205.

[15] Roberts, S. A.; Weichsel, A.; Grass, G.; Thakali, K.; Hazzard, J. T.; Tollin, G.; Rensing, C.; Montfort, W. R., Crystal Structure and Electron Transfer Kinetics of CueO, A Multicopper Oxidase Required for Copper Homeostasis in Escherichia coli. Proc. Natl. Acad. Sci. USA 2002, 99, 27662771.

[16] Shin, W.; Sundaram, U. M.; Cole, J. L.; Zhang, H. H.; Hedman, B.; Hodgson, K. O.; Solomon, E. I., Chemical and Spectroscopic Definition of the Peroxide-Level Intermediate in the Multicopper Oxidases: Relevance to the Catalytic Mechanism of Dioxygen Reduction to Water. J. Am. Chem. Soc. 1996, 118, 3202-3215.

[17] Chalupský, J.; Neese, F.; Solomon, E. I.; Ryde, U.; Rulíšek, L., Multireference Ab Initio Calculations on Reaction Intermediates of the Multicopper Oxidases. Inorg. Chem. 2006, 45, 11051-11059.

[18] Ryde, U.; Hsiao, Y.-W.; Rulíšek, L.; Solomon, E. I., Identification of the Peroxy Adduct in Multicopper Oxidases by a Combination of Computational Chemistry and Extended X-ray Absorption Fine-Structure Measurements. J. Am. Chem. Soc. 2007, 129, 726-727.

[19] Vancoillie, S.; Chalupský, J.; Ryde, U.; Solomon, E. I.; Pierloot, K.; Neese, F.; Rulíšek, L., Multireference $A b$ Initio Calculations of $g$ Tensors for Trinuclear Copper Clusters in Multicopper Oxidases. J. Phys. Chem. B 2010, 114, 7692-7702.

[20] Yoon, J.; Solomon, E. I., Electronic Structure of the Peroxy Intermediate and Its Correlation to the Native Intermediate in the Multicopper Oxidases: Insights into the Reductive Cleavage of the O-O Bond. J. Am. Chem. Soc. 2007, 129, 13127-13136. 
[21] Augustine, A. J.; Quintanar, L.; Stoj, C. S.; Kosman, D. J.; Solomon, E. I., Spectroscopic and Kinetic Studies of Perturbed Trinuclear Copper Clusters: The Role of Protons in Reductive Cleavage of the O-O Bond in the Multicopper Oxidase Fet3p. J. Am. Chem. Soc. 2007, 129, 13118-13126.

[22] Zhekova, H.; Seth, M.; Ziegler, T., Density Functional Theory Studies on the Structure and Electron Distribution in the Peroxide Intermediate of the Catalytic Cycle of Multicopper Oxidases. Can. J. Chem. 2013, 91, 847-858.

[23] Lee, S.-K.; George, S. D.; Antholine, W. E.; Hedman, B.; Hodgson, K. O.; Solomon, E. I., Nature of the Intermediate Formed in the Reduction of $\mathrm{O}_{2}$ to $\mathrm{H}_{2} \mathrm{O}$ at the Trinuclear Copper Cluster Active Site in Native Laccase. J. Am. Chem. Soc. 2002, 124, 6180-6193.

[24] Yoon, J.; Mirica, L. M.; Stack, T. D. P.; Solomon, E. I., Variable-Temperature, Variable-Field Magnetic Circular Dichroism Studies of Tris-Hydroxy- and $\mu_{3}$-Oxo-Bridged Trinuclear $\mathrm{Cu}(\mathrm{II})$ Complexes: Evaluation of Proposed Structures of the Native Intermediate of the Multicopper Oxidases. J. Am. Chem. Soc. 2005, 127, 13680-13693.

[25] Heppner, D. E.; Kjaergaard, C. H.; Solomon, E. I., Molecular Origin of Rapid versus Slow Intramolecular Electron Transfer in the Catalytic Cycle of the Multicopper Oxidases. J. Am. Chem. Soc. 2013, 135, 12212-12215.

[26] Srnec, M.; Ryde, U.; Rulišek, L., Reductive cleavage of the O-O bond in multicopper oxidases: a QM/MM and QM study. Faraday. Discuss. 2011, 148, 41-53.

[27] Kjaergaard, C. H.; Durand, F.; Tasca, F.; Qayyum, M. F.; Kauffmann, B.; Gounel, S.; Suraniti, E.; Hodgson, K. O.; Hedman, B.; Mano, N.; Solomon, E. I., Spectroscopic and Crystallographic Characterization of "Alternative Resting" and "Resting Oxidized" Enzyme Forms of Bilirubin Oxidase: Implications for Activity and Electrochemical Behavior of Multicopper Oxidases. J. Am. Chem. Soc. 2012, 134, 5548-5551.

[28] Bento, I.; Silva, C.; Chen, Z.; Martins, L.; Lindley, P.; Soares, C., Mechanisms Underlying Dioxygen Reduction in Laccases. Structural and Modelling Studies Focusing on Proton Transfer. BMC Struct. Biol. 2010, 10, 28,1-14.

[29] S. Katekaew, B. K., T. Torikata, Y. Kakuta, M. Kimura, K. Yoneda and T. Araki, Structure of the Newly Found Freen Turtle Egg-white RIbonuclease. Acta Cryst. 2010, F66, 755-759.

[30] Heppner, D. E.; Kjaergaard, C. H.; Solomon, E. I., Mechanism of the Reduction of the Native Intermediate in the Multicopper Oxidases: Insights into Rapid Intramolecular Electron Transfer in Turnover. J. Am. Chem. Soc. 2014, 136, 17788-17801.

[31] Hummer, G.; Pratt, L. R.; García, A. E., Molecular Theories and Simulation of lons and Polar Molecules in Water. J. Phys. Chem. A 1998, 102, 7885-7895.

[32] Heimdal, J.; Kaukonen, M.; Srnec, M.; Rulíšek, L.; Ryde, U., Reduction Potentials and Acidity Constants of Mn Superoxide Dismutase Calculated by QM/MM Free-Energy Methods. ChemPhysChem 2011, 12, 3337-3347.

[33] Cheng, J.; Liu, X.; VandeVondele, J.; Sulpizi, M.; Sprik, M., Redox Potentials and Acidity Constants from Density Functional Theory Based Molecular Dynamics. Acc. Chem. Res. 2014, 47, 3522-3529.

[34] Ullmann, G. M.; Knapp, E.-W., Electrostatic Models for Computing Protonation and Redox Equilibria in Proteins. Eur. Biophys. J. 1999, 28, 533-551.

[35] Noodleman, L.; Han, W.-G., Structure, Redox, pK $\mathrm{a}_{\mathrm{a}}$, Spin. A Golden Tetrad for Understanding Metalloenzyme Energetics and Reaction Pathways. J. Biol. Inorg. Chem. 2006, 11, 674-694.

[36] Olsson, M. H. M.; Hong, G.; Warshel, A., Frozen Density Functional Free Energy Simulations of Redox Proteins: Computational Studies of the Reduction Potential of Plastocyanin and Rusticyanin. J. Am. Chem. Soc. 2003, 125, 5025-5039.

[37] Blumberger, J., Free Energies for Biological Electron Transfer from QM/MM Calculation: Method, Application and Critical Assessment. Phys. Chem. Chem. Phys. 2008, 10, 5651-5667.

[38] Marenich, A. V.; Ho, J.; Coote, M. L.; Cramer, C. J.; Truhlar, D. G., Computational Electrochemistry: Prediction of Liquid-Phase Reduction Potentials. Phys. Chem. Chem. Phys. 2014, 16, 15068-15106.

[39] Datta, S. N.; Sudhamsu, J.; Pandey, A., Theoretical Determination of the Standard Reduction Potential of Plastocyanin in Vitro. J. Phys. Chem. B 2004, 108, 8007-8016. 
[40] Cascella, M.; Magistrato, A.; Tavernelli, I.; Carloni, P.; Rothlisberger, U., Role of Protein Frame and Solvent for the Redox Properties of Azurin from Pseudomonas Aeruginosa. Proc. Natl. Acad. Sci. USA 2006, 103, 19641-19646.

[41] Barone, V.; De Rienzo, F.; Langella, E.; Menziani, M. C.; Rega, N.; Sola, M., A Computational Protocol to Probe the Role of Solvation Effects on the Reduction Potential of Azurin Mutants. Proteins 2006, 62, 262-269.

[42] Hong, G.; Ivnitski, D. M.; Johnson, G. R.; Atanassov, P.; Pachter, R., Design Parameters for Tuning the Type $1 \mathrm{Cu}$ Multicopper Oxidase Redox Potential: Insight from a Combination of First Principles and Empirical Molecular Dynamics Simulations. J. Am. Chem. Soc. 2011, 133, 48024809.

[43] Hu, L.; Farrokhnia, M.; Heimdal, J.; Shleev, S.; Rulíšek, L.; Ryde, U., Reorganization Energy for Internal Electron Transfer in Multicopper Oxidases. J. Phys. Chem. B 2011, 115, 1311113126.

[44] Schutz, C. N.; Warshel, A., What Are the Dielectric "Constants" of Proteins and How to Validate Electrostatic Models? Prot. Struct. Funct. Gen. 2001, 44, 400-417.

[45] Li, H.; Hains, A. W.; Everts, J. E.; Robertson, A. D.; Jensen, J. H., The Prediction of Protein pKa's Using QM/MM: The $\mathrm{pK}_{\mathrm{a}}$ of Lysine 55 in Turkey Ovomucoid Third Domain. J. Phys. Chem. B 2002, 106, 3486-3494.

[46] Kelly, C. P.; Cramer, C. J.; Truhlar, D. G., Adding Explicit Solvent Molecules to Continuum Solvent Calculations for the Calculation of Aqueous Acid Dissociation Constants. J. Phys. Chem. A 2006, 110, 2493-2499.

[47] Riccardi, D.; Cui, Q., $\mathrm{pK}_{\mathrm{a}}$ Analysis for the Zinc-Bound Water in Human Carbonic Anhydrase II: Benchmark for "Multiscale" QM/MM Simulations and Mechanistic Implications. J. Phys. Chem. A 2007, 111, 5703-5711.

[48] Alexov, E.; Mehler, E. L.; Baker, N.; M. Baptista, A.; Huang, Y.; Milletti, F.; Erik Nielsen, J.; Farrell, D.; Carstensen, T.; Olsson, M. H. M.; Shen, J. K.; Warwicker, J.; Williams, S.; Word, J. M., Progress in the Prediction of $\mathrm{pK}_{\mathrm{a}}$ Values in Proteins. Proteins 2011, 79, 3260-3275.

[49] Ullmann, G. M.; Bombarda, E., pK $\mathrm{p}_{\mathrm{a}}$ Values and Redox Potentials of Proteins. What Do They Mean? Biol. Chem. 2013, 394, 611-619.

[50] Sharp, K. A.; Honig, B., Electrostatic Interactions in Macromolecules: Theory and Applications. Annu. Rev. Biophys. Biophys. Chem. 1990, 19, 301-332.

[51] Orozco, M.; Luque, F. J., Theoretical Methods for the Description of the Solvent Effect in Biomolecular Systems. Chem. Rev. 2000, 100, 4187-4226.

[52] Åqvist, J.; Warshel, A., Computer Simulation of the Initial Proton Transfer Step in Human Carbonic Anhydrase I. J. Mol. Biol. 1992, 224, 7-14.

[53] Ghosh, N.; Prat-Resina, X.; Gunner, M. R.; Cui, Q., Microscopic pK ${ }_{a}$ Analysis of Glu286 in Cytochrome c Oxidase (Rhodobacter sphaeroides): Toward a Calibrated Molecular Model. Biochem. 2009, 48, 2468-2485.

[54] Klingen, A. R.; Ullmann, G. M., Negatively Charged Residues and Hydrogen Bonds Tune the Ligand Histidine pKa Values of Rieske Iron-Sulfur Proteins. Biochem. 2004, 43, 12383-12389.

[55] Weis, A.; Katebzadeh, K.; Söderhjelm, P.; Nilsson, I.; Ryde, U., Ligand Affinities Predicted with the MM/PBSA Method: Dependence on the Simulation Method and the Force Field. J. Med. Chem. 2006, 49, 6596-6606.

[56] Ryde, U., The Coordination of the Catalytic Zinc in Alcohol Dehydrogenase Studied by Combined Quantum-Chemical and Molecular Mechanics Calculations. J. Comput. Aided Mol. Des. 1996, 10, 153-164.

[57] Ryde, U.; Olsson, M. H. M., Structure, Strain, and Reorganization Energy of Blue Copper Models in the Protein. Int. J. Quantum. Chem. 2001, 81, 335-347.

[58] TURBOMOLE V6.5 2013, a development of University of Karlsruhe and Forschungszentrum Karlsruhe $\mathrm{GmbH}, 1989-2007$, TURBOMOLE GmbH, since 2007; available from http://www.turbomole.com.

[59] Case, D. A.; Darden, T. A.; Cheatham, T. E.; Simmerling, C. L.; Wang, J.; Duke, R. E.; Luo, R.; Crowley, M.; Walker, R. C.; Zhang, W.; et al., AMBER 10, University of California, San Francisco. 2008.

[60] Hu, L.; Söderhjelm, P.; Ryde, U., On the Convergence of QM/MM Energies. J. Chem. Theory Comput. 2011, 7, 761-777. 
[61] Kaukonen, M.; Söderhjelm, P.; Heimdal, J.; Ryde, U., QM/MM-PBSA Method To Estimate Free Energies for Reactions in Proteins. J. Phys. Chem. B 2008, 112, 12537-12548.

[62] Besler, B. H.; Merz, K. M.; Kollman, P. A., Atomic Charges Derived from Semiempirical Methods. J. Comput. Chem. 1990, 11, 431-439.

[63] Rod, T. H.; Ryde, U., Quantum Mechanical Free Energy Barrier for an Enzymatic Reaction. Phys. Rev. Lett. 2005, 94, 138302.

[64] Rod, T. H.; Ryde, U., Accurate QM/MM Free Energy Calculations of Enzyme Reactions: Methylation by Catechol O-Methyltransferase. J. Chem. Theory Comput. 2005, 1, 1240-1251.

[65] Kästner, J.; Senn, H. M.; Thiel, S.; Otte, N.; Thiel, W., QM/MM Free-Energy Perturbation Compared to Thermodynamic Integration and Umbrella Sampling: Application to an Enzymatic Reaction. J. Chem. Theory Comput. 2006, 2, 452-461.

[66] Ryde, U.; Kaukonen, M.; Soderhjelm, P.; Heimdal, J., Proton Transfer at Metal Sites in Proteins Studied by Quantum Mechanical Free-Energy Perturbations. J. Chem. Theory Comput. 2008, 4, 985-1001.

[67] Yang, W.; Bitetti-Putzer, R.; Karplus, M., Free Energy Simulations: Use of Reverse Cumulative Averaging to Determine the Equilibrated Region and the Time Required for Convergence. J. Chem. Phys. 2004, 120, 2618-2628.

[68] Böttcher, C. J. F., Theory of electric polarization. Elsevier Scientific Pub. Co: Amsterdam, New York, 1973.

[69] Onufriev, A.; Bashford, D.; Case, D. A., Exploring Protein Native States and Large-Scale Conformational Changes with A Modified Generalized Born Model. Proteins 2004, 55, 383-394.

[70] Riccardi, D.; Schaefer, P.; Cui, Q., $\mathrm{pK}_{\mathrm{a}}$ Calculations in Solution and Proteins with QM/MM Free Energy Perturbation Simulations: A Quantitative Test of QM/MM Protocols. J. Phys. Chem. B 2005, 109, 17715-17733.

[71] Boresch, S., The Role of Bonded Energy Terms in Free Energy Simulations - Insights from Analytical Results. Molecular Simulation 2002, 28, 13-37.

[72] Kollman, P. A.; Massova, I.; Reyes, C.; Kuhn, B.; Huo, S.; Chong, L.; Lee, M.; Lee, T.; Duan, Y.; Wang, W.; Donini, O.; Cieplak, P.; Srinivasan, J.; Case, D. A.; Cheatham, T. E., Calculating Structures and Free Energies of Complex Molecules: Combining Molecular Mechanics and Continuum Models. Acc. Chem. Res. 2000, 33, 889-897.

[73] Kuhn, B.; Kollman, P. A., Binding of a Diverse Set of Ligands to Avidin and Streptavidin: An Accurate Quantitative Prediction of Their Relative Affinities by a Combination of Molecular Mechanics and Continuum Solvent Models. J. Med. Chem. 2000, 43, 3786-3791.

[74] Perdew, J. P.; Burke, K.; Ernzerhof, M., Generalized Gradient Approximation Made Simple. Phys. Rev. Lett. 1996, 77, 3865-3868.

[75] Weigend, F.; Ahlrichs, R., Balanced Basis Sets of Split Valence, Triple Zeta Valence and Quadruple Zeta Valence Quality for H to Rn: Design and Assessment of Accuracy. Phys. Chem. Chem. Phys. 2005, 7, 3297-3305.

[76] Lee, C.; Yang, W.; Parr, R. G., Development of the Colle-Salvetti Correlation-Energy Formula into A Functional of the Electron Density. Phys. Rev. B 1988, 37, 785-789.

[77] Becke, A. D., Density $\square$ Functional Thermochemistry. III. The Role of Exact Exchange. J. Chem. Phys. 1993, 98, 5648-5652.

[78] Rappoport, D.; Furche, F., Property-Optimized Gaussian Basis Sets for Molecular Response Calculations. J. Chem. Phys. 2010, 133, 134105.

[79] Eichkorn, K.; Treutler, O.; Öhm, H.; Häser, M.; Ahlrichs, R., Auxiliary Basis Sets to Approximate Coulomb Potentials. Chem. Phys. Lett. 1995, 240, 283-289.

[80] Eichkorn, K.; Weigend, F.; Treutler, O.; Ahlrichs, R., Auxiliary Basis Sets for Main Row Atoms and Transition Metals and Their Use to Approximate Coulomb Potentials. Theor. Chem. Acc. 1997, 97, 119-124.

[81] Grimme, S.; Antony, J.; Ehrlich, S.; Krieg, H., A Consistent and Accurate ab initio Parametrization of Density Functional Dispersion Correction (DFT-D) for the 94 Elements $\mathrm{H}-\mathrm{Pu}$. $J$. Chem. Phys. 2010, 132, 154104, 1-11.

[82] Grimme, S.; Ehrlich, S.; Goerigk, L., Effect of the Damping Function in Dispersion Corrected Density Functional Theory. J. Comput. Chem. 2011, 32, 1456-1465.

[83] http://www.thch.uni-bonn.de/tc/index.php?section=downloads\&subsection=getd3 
[84] Noodleman, L.; Davidson, E. R., Ligand Spin Polarization and Antiferromagnetic Coupling in Transition Metal Dimers. Chem. Phys. 1986, 109, 131-143.

[85] Hornak, V.; Abel, R.; Okur, A.; Strockbine, B.; Roitberg, A.; Simmerling, C., Comparison of Multiple Amber Force Fields and Development of Improved Protein Backbone Parameters. Proteins 2006, 65, 712-725.

[86] Ryckaert, J.-P.; Ciccotti, G.; Berendsen, H. J. C., Numerical Integration of the Cartesian Equations of Motion of a System with Constraints: Molecular Dynamics of $n$-Alkanes. J. Comput. Phys. 1977, 23, 327-341.

[87] Essmann, U.; Perera, L.; Berkowitz, M. L.; Darden, T.; Lee, H.; Pedersen, L. G., A Smooth Particle Mesh Ewald Method. J. Chem. Phys. 1995, 103, 8577-8593.

[88] Darden, T.; York, D.; Pedersen, L., Particle mesh Ewald: An N $\square \log (\mathrm{N})$ Method for Ewald Sums in Large Systems. J. Chem. Phys. 1993, 98, 10089-10092.

[89] Berendsen, H. J. C.; Postma, J. P. M.; van Gunsteren, W. F.; DiNola, A.; Haak, J. R., Molecular Dynamics with Coupling to An External Bath. J. Chem. Phys. 1984, 81, 3684-3690.

[90] Jorgensen, W. L.; Chandrasekhar, J.; Madura, J. D.; Impey, R. W.; Klein, M. L., Comparison of Simple Potential Functions for Simulating Liquid Water. J. Chem. Phys. 1983, 79, 926-935.

[91] Miura, Y.; Tsujimura, S.; Kurose, S.; Kamitaka, Y.; Kataoka, K.; Sakurai, T.; Kano, K., Direct Electrochemistry of CueO and Its Mutants at Residues to and Near Type I $\mathrm{Cu}$ for OxygenReducing Biocathode. Fuel Cells 2009, 9, 70-78.

[92] Quintanar, L.; Yoon, J.; Aznar, C. P.; Palmer, A. E.; Andersson, K. K.; Britt, R. D.; Solomon, E. I., Spectroscopic and Electronic Structure Studies of the Trinuclear Cu Cluster Active Site of the Multicopper Oxidase Laccase: Nature of Its Coordination Unsaturation. J. Am. Chem. Soc. 2005, 127, 13832-13845.

[93] Jensen, F., Introduction to Computational Chemistry. 2ed.; John Wiley \& Sons Ltd.: Chichester, UK, 2007.

[94] Dunitz, J. D., The Entropic Cost of Bound Water in Crystals and Biomolecules. Science 1994, 264, 670 .

[95] Irudayam, S. J.; Henchman, R. H., Entropic Cost of Protein-Ligand Binding and Its Dependence on the Entropy in Solution. J. Phys. Chem. B 2009, 113, 5871-5884.

[96] Rulíšek, L.; Jensen, K. P.; Lundgren, K.; Ryde, U., The Reaction Mechanism of Iron and Manganese Superoxide Dismutases Studied by Theoretical Calculations. J. Comput. Chem. 2006, 27, 1398-1414.

[97] Jensen, K. P.; Ryde, U., Theoretical Prediction of the Co-C Bond Strength in Cobalamins. J. Phys. Chem. A 2003, 107, 7539-7545.

[98] Li, J. L.; Mata, R. A.; Ryde, U., Large Density-Functional and Basis-Set Effects for the DMSO Reductase Catalyzed Oxo-Transfer Reaction. J. Chem. Theory Comput. 2013, 9, 17991807. 
Table 1. Redox potentials for the various TNC states relative to the $\mathrm{Cu}_{\mathrm{T} 1}$ site $\left(\Delta E^{\circ}\right.$ in $\left.\mathrm{V}\right)$, calculated with QTCP. The protonation state of all ligands are the same in both oxidation states so the symbols in brackets for the former state are omitted. The more stable TNC state is marked in bold face, i.e. the reduced TNC state if $\Delta E^{\circ}>0$ and the oxidised state otherwise.

\begin{tabular}{|c|c|}
\hline TNC states & $\Delta E^{\circ}$ \\
\hline$\overline{\mathrm{Pl} \rightarrow \mathbf{N I}\left(\mathrm{H}_{2} \mathrm{O}, \mathrm{HO}_{2}\right)}$ & $2.36 \pm 0.02$ \\
\hline $\mathrm{PI} \rightarrow \mathbf{N I}^{\prime}\left(\mathrm{H}_{2} \mathrm{O}, \mathrm{O}_{2}\right)$ & $0.35 \pm 0.02$ \\
\hline $\mathrm{PI} \rightarrow \mathbf{N I}\left(\mathrm{OH}, \mathrm{HO}_{2}\right)$ & $1.08 \pm 0.02$ \\
\hline $\mathrm{PI} \rightarrow \mathrm{NI}\left(\mathrm{OH}, \mathrm{O}_{2}\right)$ & $-1.42 \pm 0.02$ \\
\hline $\mathrm{NI} \rightarrow \mathbf{I O x}\left(\mathrm{H}_{2} \mathrm{O}, \mathrm{H}_{2} \mathrm{O}, \mathrm{O}\right)$ & $1.61 \pm 0.02$ \\
\hline $\mathrm{NI} \rightarrow \mathrm{IOx}\left(\mathrm{H}_{2} \mathrm{O}, \mathrm{OH}, \mathrm{O}\right)$ & $0.03 \pm 0.02$ \\
\hline $\mathrm{NI} \rightarrow \mathrm{IOx}(\mathrm{OH}, \mathrm{OH}, \mathrm{O})$ & $-1.45 \pm 0.02$ \\
\hline $\mathrm{IOx} \rightarrow \mathrm{IRed}\left(\mathrm{H}_{2} \mathrm{O}, \mathrm{H}_{2} \mathrm{O}, \mathrm{O}\right)$ & $0.35 \pm 0.02$ \\
\hline $\mathrm{IO} x \rightarrow \operatorname{Red}\left(\mathrm{H}_{2} \mathrm{O}, \mathrm{OH}, \mathrm{O}\right)$ & $-1.68 \pm 0.02$ \\
\hline $\mathrm{IO} x \rightarrow \operatorname{Red}(\mathrm{OH}, \mathrm{OH}, \mathrm{OH})$ & $-1.37 \pm 0.02$ \\
\hline $\mathrm{IOx} \rightarrow \operatorname{IRed}\left(\mathrm{H}_{2} \mathrm{O}, \mathrm{OH}\right)$ & $2.28 \pm 0.02$ \\
\hline $\mathrm{IOx} \rightarrow \operatorname{IRed}\left(\mathrm{H}_{2} \mathrm{O}, \mathrm{O}\right)$ & $0.59 \pm 0.02$ \\
\hline $\mathrm{IOx} \rightarrow \mathrm{IRed}(\mathrm{OH}, \mathrm{OH})$ & $1.35 \pm 0.02$ \\
\hline $\mathrm{IOx} \rightarrow \mathrm{IRed}(\mathrm{OH}, \mathrm{O})$ & $-1.04 \pm 0.02$ \\
\hline$\overline{\mathrm{IRed} \rightarrow \operatorname{Red}\left(\mathrm{H}_{2} \mathrm{O}, \mathrm{H}_{2} \mathrm{O}\right)}$ & $2.42 \pm 0.02$ \\
\hline IRed $\rightarrow \operatorname{Red}\left(\mathrm{H}_{2} \mathrm{O}, \mathrm{OH}\right)$ & $0.16 \pm 0.02$ \\
\hline IRed $\rightarrow \operatorname{Red}\left(\mathrm{H}_{2} \mathrm{O}, \mathrm{O}\right)$ & $-1.30 \pm 0.03$ \\
\hline IRed $\rightarrow \operatorname{Red}(\mathrm{OH}, \mathrm{OH})$ & $-0.38 \pm 0.02$ \\
\hline $\mathrm{IRed} \rightarrow \operatorname{Red}\left(\mathrm{H}_{2} \mathrm{O},-\right)$ & $2.72 \pm 0.02$ \\
\hline $\mathrm{Ox} \rightarrow \mathbf{I O x}\left(\mathrm{H}_{2} \mathrm{O}, \mathrm{OH}\right)$ & $4.72 \pm 0.01$ \\
\hline $\mathrm{Ox} \rightarrow \mathrm{IOx}(\mathrm{OH}, \mathrm{OH})$ & $2.52 \pm 0.02$ \\
\hline
\end{tabular}


Table 2. Calculated $p K_{a}$ values for the various states of TNC relative to Asp-373, calculated with QTCP. Results are given both with the $\mathrm{Cu}_{\mathrm{T} 1}$ site reduced and oxidised. The more stable TNC state at $\mathrm{pH} 7$ is marked in bold face, i.e. the protonated state if the $\mathrm{pK}_{\mathrm{a}}$ value is larger than 3 and the deprotonated state otherwise.

\begin{tabular}{|c|c|c|}
\hline TNC states & $\mathrm{Cu}_{\mathrm{T} 1}$ oxidised & $\mathrm{Cu}_{\mathrm{T} 1}$ reduced \\
\hline$\overline{\mathrm{Pl}}\left(\mathrm{H}_{2} \mathrm{O}, \mathrm{HO}_{2}\right) \rightarrow\left(\mathrm{H}_{2} \mathbf{O}, \mathbf{O}_{2}\right)$ & $-45.7 \pm 0.6$ & $-43.0 \pm 0.6$ \\
\hline $\mathrm{PI}\left(\mathrm{H}_{2} \mathrm{O}, \mathrm{HO}_{2}\right) \rightarrow\left(\mathrm{OH}, \mathrm{HO}_{2}\right)$ & $-31.2 \pm 0.7$ & $-28.7 \pm 0.7$ \\
\hline $\mathrm{PI}\left(\mathrm{H}_{2} \mathrm{O}, \mathrm{O}_{2}\right) \rightarrow\left(\mathrm{OH}, \mathrm{O}_{2}\right)$ & $-8.6 \pm 0.7$ & $-4.7 \pm 0.7$ \\
\hline $\mathrm{Pl}\left(\mathrm{OH}, \mathrm{HO}_{2}\right) \rightarrow\left(\mathrm{OH}, \mathrm{O}_{2}\right)$ & $-22.3 \pm 0.6$ & $-18.1 \pm 0.6$ \\
\hline $\mathrm{Nl}^{\prime}\left(\mathrm{H}_{2} \mathrm{O}, \mathrm{HO}_{2}\right) \rightarrow\left(\mathbf{H}_{\mathbf{2}} \mathbf{O}, \mathbf{O}_{\mathbf{2}}\right)$ & $-10.4 \pm 0.6$ & $-6.1 \pm 0.6$ \\
\hline $\mathrm{NI}^{\prime}\left(\mathrm{H}_{2} \mathrm{O}, \mathrm{HO}_{2}\right) \rightarrow\left(\mathrm{OH}, \mathrm{HO}_{2}\right)$ & $-2.7 \pm 0.8$ & $0.8 \pm 0.8$ \\
\hline $\mathrm{NI}^{\prime}\left(\mathrm{H}_{2} \mathrm{O}, \mathrm{O}_{2}\right) \rightarrow\left(\mathrm{OH}, \mathrm{O}_{2}\right)$ & $25.9 \pm 0.8$ & $28.4 \pm 0.8$ \\
\hline $\mathrm{NI}\left(\mathrm{OH}, \mathrm{HO}_{2}\right) \rightarrow\left(\mathrm{OH}, \mathrm{O}_{2}\right)$ & $17.7 \pm 0.6$ & $20.7 \pm 0.6$ \\
\hline$\overline{\mathrm{NI}}\left(\mathrm{H}_{2} \mathrm{O}, \mathrm{H}_{2} \mathrm{O}, \mathrm{O}\right) \rightarrow\left(\mathrm{H}_{2} \mathrm{O}, \mathrm{OH}, \mathrm{O}\right)$ & $-46.4 \pm 0.6$ & $-44.3 \pm 0.6$ \\
\hline $\mathrm{NI}\left(\mathrm{H}_{2} \mathrm{O}, \mathrm{OH}, \mathrm{OH}\right) \rightarrow\left(\mathrm{H}_{2} \mathrm{O}, \mathrm{OH}, \mathrm{O}\right)$ & $-35.1 \pm 0.6$ & $-34.2 \pm 0.6$ \\
\hline $\mathrm{NI}\left(\mathrm{H}_{2} \mathrm{O}, \mathrm{OH}, \mathrm{O}\right) \rightarrow\left(\mathrm{H}_{2} \mathrm{O}, \mathrm{O}, \mathrm{O}\right)$ & $15.5 \pm 0.6$ & $18.7 \pm 0.6$ \\
\hline $\mathrm{NI}\left(\mathrm{H}_{2} \mathrm{O}, \mathrm{OH}, \mathrm{O}\right) \rightarrow(\mathrm{OH}, \mathrm{OH}, \mathrm{O})$ & $-11.2 \pm 0.7$ & $-10.7 \pm 0.7$ \\
\hline $\mathrm{IOx}\left(\mathrm{H}_{2} \mathrm{O}, \mathrm{H}_{2} \mathrm{O}, \mathrm{OH}\right) \rightarrow\left(\mathrm{H}_{2} \mathbf{O}, \mathrm{H}_{2} \mathbf{O}, \mathbf{O}\right)$ & $-24.9 \pm 2.1$ & $-18.6 \pm 3.3$ \\
\hline $\mathrm{IOx}\left(\mathrm{H}_{2} \mathrm{O}, \mathrm{H}_{2} \mathrm{O}, \mathrm{O}\right) \rightarrow\left(\mathrm{H}_{2} \mathrm{O}, \mathrm{OH}, \mathrm{O}\right)$ & $-9.5 \pm 2.4$ & $-7.7 \pm 3.1$ \\
\hline $\mathrm{IOx}\left(\mathrm{H}_{2} \mathrm{O}, \mathrm{H}_{2} \mathrm{O}, \mathrm{O}\right) \rightarrow\left(\mathrm{OH}, \mathrm{H}_{2} \mathrm{O}, \mathrm{O}\right)$ & $-6.7 \pm 1.9$ & $-2.8 \pm 1.4$ \\
\hline $\mathrm{IOx}\left(\mathrm{H}_{2} \mathrm{O}, \mathrm{OH}, \mathrm{OH}\right) \rightarrow(\mathrm{OH}, \mathrm{OH}, \mathrm{OH})$ & $-12.6 \pm 0.7$ & $-9.9 \pm 0.7$ \\
\hline $\mathrm{IOx}\left(\mathrm{H}_{2} \mathrm{O}, \mathrm{OH}, \mathrm{O}\right) \rightarrow(\mathrm{OH}, \mathrm{OH}, \mathrm{O})$ & $14.1 \pm 0.7$ & $15.8 \pm 0.7$ \\
\hline $\mathrm{IOx}\left(\mathrm{H}_{2} \mathrm{O}, \mathrm{OH}, \mathrm{O}\right) \rightarrow\left(\mathrm{H}_{2} \mathrm{O}, \mathrm{O}, \mathrm{O}\right)$ & $34.4 \pm 0.6$ & $38.1 \pm 0.6$ \\
\hline $\mathrm{IOx}\left(\mathrm{OH}, \mathrm{H}_{2} \mathrm{O}, \mathrm{O}\right) \rightarrow(\mathrm{OH}, \mathrm{OH}, \mathrm{O})$ & $12.4 \pm 0.6$ & $15.5 \pm 0.6$ \\
\hline $\mathrm{IOx}(\mathrm{OH}, \mathrm{OH}, \mathrm{OH}) \rightarrow(\mathrm{OH}, \mathrm{OH}, \mathrm{O})$ & $22.9 \pm 0.7$ & $26.1 \pm 0.7$ \\
\hline $\mathrm{IOx}\left(\mathrm{H}_{2} \mathrm{O}, \mathrm{OH}\right) \rightarrow\left(\mathrm{H}_{2} \mathrm{O}, \mathrm{O}\right)$ & $-28.0 \pm 0.6$ & $-26.7 \pm 0.6$ \\
\hline $\mathrm{IOx}\left(\mathrm{H}_{2} \mathrm{O}, \mathrm{OH}\right) \rightarrow(\mathrm{OH}, \mathrm{OH})$ & $-24.4 \pm 0.6$ & $-23.9 \pm 0.6$ \\
\hline $\mathrm{IOx}\left(\mathrm{H}_{2} \mathrm{O}, \mathrm{O}\right) \rightarrow(\mathrm{OH}, \mathrm{O})$ & $-11.1 \pm 0.7$ & $-8.0 \pm 0.8$ \\
\hline $\mathrm{IOx}(\mathrm{OH}, \mathrm{OH}) \rightarrow(\mathrm{OH}, \mathrm{O})$ & $-14.9 \pm 0.6$ & $-12.1 \pm 0.7$ \\
\hline $\mathrm{IRed}\left(\mathrm{H}_{2} \mathrm{O}, \mathrm{H}_{2} \mathrm{O}, \mathrm{OH}\right) \rightarrow\left(\mathbf{H}_{\mathbf{2}} \mathbf{O}, \mathrm{H}_{\mathbf{2}} \mathbf{O}, \mathbf{O}\right)$ & $-14.5 \pm 0.9$ & $-8.2 \pm 1.1$ \\
\hline $\mathrm{IRed}\left(\mathrm{H}_{2} \mathrm{O}, \mathrm{H}_{2} \mathrm{O}, \mathrm{OH}\right) \rightarrow\left(\mathrm{OH}, \mathrm{H}_{2} \mathrm{O}, \mathrm{OH}\right)$ & $-18.5 \pm 0.7$ & $-18.1 \pm 0.7$ \\
\hline$I \operatorname{Red}\left(\mathbf{H}_{2} \mathbf{O}, \mathbf{H}_{2} \mathbf{O}, \mathbf{O}\right) \rightarrow\left(\mathrm{H}_{2} \mathrm{O}, \mathrm{OH}, \mathrm{O}\right)$ & $26.9 \pm 0.7$ & $27.3 \pm 0.7$ \\
\hline $\mathrm{IRed}\left(\mathrm{OH}, \mathrm{H}_{2} \mathrm{O}, \mathrm{OH}\right) \rightarrow(\mathrm{OH}, \mathrm{OH}, \mathrm{OH})$ & $30.3 \pm 0.8$ & $26.1 \pm 0.8$ \\
\hline$I \operatorname{Red}\left(\mathrm{H}_{2} \mathrm{O}, \mathrm{H}_{2} \mathrm{O}\right) \rightarrow\left(\mathrm{H}_{2} \mathrm{O}, \mathbf{O H}\right)$ & $-45.0 \pm 0.6$ & $-42.3 \pm 0.6$ \\
\hline $\mathrm{IRed}\left(\mathrm{H}_{2} \mathrm{O}, \mathrm{OH}\right) \rightarrow(\mathrm{OH}, \mathrm{OH})$ & $1.3 \pm 0.7$ & $5.0 \pm 0.7$ \\
\hline $\mathrm{IRed}\left(\mathrm{H}_{2} \mathrm{O}, \mathrm{OH}\right) \rightarrow\left(\mathrm{H}_{2} \mathrm{O}, \mathrm{O}\right)$ & $5.7 \pm 0.6$ & $9.3 \pm 0.6$ \\
\hline $\mathrm{IRed}\left(\mathbf{H}_{\mathbf{2}} \mathbf{O}, \mathbf{O}\right) \rightarrow(\mathrm{OH}, \mathrm{O})$ & $17.0 \pm 0.9$ & $18.0 \pm 0.9$ \\
\hline IRed(OH,OH $) \rightarrow(\mathrm{OH}, \mathrm{O})$ & $15.5 \pm 0.6$ & $16.7 \pm 0.7$ \\
\hline$\overline{\operatorname{Red}\left(\mathrm{H}_{2} \mathrm{O}, \mathrm{H}_{2} \mathrm{O}\right) \rightarrow\left(\mathrm{H}_{2} \mathrm{O}, \mathrm{OH}\right)}$ & $-6.4 \pm 0.6$ & $-2.9 \pm 0.6$ \\
\hline $\operatorname{Red}\left(\mathrm{H}_{2} \mathrm{O}, \mathrm{H}_{2} \mathrm{O}\right) \rightarrow\left(\mathrm{OH}, \mathrm{H}_{2} \mathrm{O}\right)$ & $3.0 \pm 0.7$ & $5.4 \pm 0.7$ \\
\hline $\operatorname{Red}\left(\mathrm{H}_{2} \mathrm{O}, \mathrm{OH}\right) \rightarrow\left(\mathrm{H}_{2} \mathrm{O}, \mathrm{O}\right)$ & $28.2 \pm 0.7$ & $37.9 \pm 0.6$ \\
\hline $\operatorname{Red}\left(\mathrm{H}_{2} \mathrm{O}, \mathrm{OH}\right) \rightarrow(\mathrm{OH}, \mathrm{OH})$ & $17.4 \pm 0.7$ & $21.2 \pm 0.7$ \\
\hline $\operatorname{Red}\left(\mathrm{OH}, \mathrm{H}_{2} \mathrm{O}\right) \rightarrow(\mathrm{OH}, \mathrm{OH})$ & $8.1 \pm 0.6$ & $11.9 \pm 0.6$ \\
\hline $\operatorname{Red}\left(\mathrm{H}_{2} \mathrm{O},-\right) \rightarrow(\mathrm{OH},-)$ & $2.6 \pm 0.7$ & $3.6 \pm 0.7$ \\
\hline$\overline{\mathrm{Ox}}\left(\mathrm{H}_{2} \mathrm{O}, \mathrm{OH}\right) \rightarrow(\mathrm{OH}, \mathrm{OH})$ & $-59.4 \pm 0.6$ & $-58.6 \pm 0.7$ \\
\hline
\end{tabular}


Table 3. Calculated isomerisation and reaction free energies (in $\mathrm{kJ} / \mathrm{mol}$ ) for the various states of TNC, calculated with QTCP. Results are given both with the $\mathrm{Cu}_{\mathrm{T} 1}$ site reduced and oxidised. The more stable state is marked in bold face, i.e. the reactant if the isomerisation energy is positive and the product state otherwise.

\begin{tabular}{|c|c|c|c|}
\hline Reactant & Product & $\mathrm{Cu}_{\mathrm{T} 1}$ oxidised & $\mathrm{Cu}_{\mathrm{T} 1}$ reduced \\
\hline $\mathrm{PI}\left(\mathrm{H}_{2} \mathrm{O}, \mathrm{O}_{2}\right)$ & $\mathrm{Pl}\left(\mathrm{OH}, \mathrm{HO}_{2}\right)$ & $78.8 \pm 1.6$ & $78.3 \pm 1.5$ \\
\hline $\mathrm{Nl}^{\prime}\left(\mathrm{H}_{2} \mathrm{O}, \mathrm{O}_{2}\right)$ & $\mathrm{NI}^{\prime}\left(\mathrm{OH}, \mathrm{HO}_{2}\right)$ & $34.5 \pm 3.0$ & $30.1 \pm 2.4$ \\
\hline $\mathrm{NI}\left(\mathrm{H}_{2} \mathrm{O}, \mathrm{H}_{2} \mathrm{O}, \mathrm{O}\right)$ & $\mathrm{NI}\left(\mathrm{H}_{2} \mathrm{O}, \mathrm{OH}, \mathrm{OH}\right)$ & $-55.5 \pm 0.7$ & $-53.7 \pm 0.6$ \\
\hline $\mathrm{NI}\left(\mathrm{H}_{2} \mathrm{O}, \mathrm{OH}, \mathrm{O}\right)$ & $\mathrm{NI}\left(\mathrm{OH}, \mathrm{H}_{2} \mathrm{O}, \mathrm{O}\right)$ & $121.9 \pm 1.7$ & $112.7 \pm 1.7$ \\
\hline $\mathrm{NI}\left(\mathrm{H}_{2} \mathrm{O}, \mathrm{OH}, \mathrm{O}\right)$ & $\mathrm{NI}(\mathrm{OH}, \mathrm{OH}, \mathrm{OH})$ & $30.5 \pm 1.4$ & $24.6 \pm 1.2$ \\
\hline $\mathrm{Nl}\left(\mathrm{H}_{2} \mathrm{O}, \mathrm{O}, \mathrm{O}\right)$ & $\mathrm{NI}(\mathrm{OH}, \mathrm{OH}, \mathrm{O})$ & $-62.6 \pm 1.7$ & $-83.5 \pm 1.8$ \\
\hline $\mathrm{IOx}\left(\mathrm{H}_{2} \mathrm{O}, \mathrm{H}_{2} \mathrm{O}, \mathrm{O}\right)$ & $\mathrm{IOx}\left(\mathrm{H}_{2} \mathrm{O}, \mathrm{OH}, \mathrm{OH}\right)$ & $-1.3 \pm 19.5$ & $-17.0 \pm 6.0$ \\
\hline $\mathrm{IOx}\left(\mathrm{H}_{2} \mathrm{O}, \mathrm{H}_{2} \mathrm{O}, \mathrm{O}\right)$ & $\mathrm{IOx}\left(\mathrm{OH}, \mathrm{H}_{2} \mathrm{O}, \mathrm{OH}\right)$ & $10.1 \pm 11.6$ & $-18.4 \pm 16.2$ \\
\hline $\mathrm{IOx}\left(\mathrm{H}_{2} \mathrm{O}, \mathrm{OH}, \mathrm{O}\right)$ & $\mathrm{IOx}\left(\mathrm{OH}, \mathrm{H}_{2} \mathrm{O}, \mathrm{O}\right)$ & $15.5 \pm 2.1$ & $8.4 \pm 2.4$ \\
\hline $\mathrm{IOx}\left(\mathrm{H}_{2} \mathrm{O}, \mathrm{OH}, \mathrm{O}\right)$ & $\mathrm{IOx}(\mathrm{OH}, \mathrm{OH}, \mathrm{OH})$ & $-41.7 \pm 2.8$ & $-41.3 \pm 2.4$ \\
\hline $\mathrm{IOx}\left(\mathrm{H}_{2} \mathrm{O}, \mathrm{O}\right)$ & $\mathrm{IOx}(\mathrm{OH}, \mathrm{OH})$ & $7.9 \pm 1.3$ & $19.5 \pm 1.2$ \\
\hline $\operatorname{IRed}\left(\mathrm{H}_{2} \mathrm{O}, \mathrm{H}_{2} \mathrm{O}, \mathrm{O}\right)$ & $\mathrm{IRed}\left(\mathrm{H}_{2} \mathrm{O}, \mathrm{OH}, \mathrm{OH}\right)$ & $35.7 \pm 18.8$ & $17.0 \pm 8.4$ \\
\hline $\mathrm{IRed}\left(\mathrm{H}_{2} \mathrm{O}, \mathrm{H}_{2} \mathrm{O}, \mathrm{O}\right)$ & $\mathrm{IRed}\left(\mathrm{OH}, \mathrm{H}_{2} \mathrm{O}, \mathrm{OH}\right)$ & $-13.7 \pm 10.7$ & $36.9 \pm 7.1$ \\
\hline $\operatorname{IRed}\left(\mathrm{H}_{2} \mathrm{O}, \mathrm{OH}, \mathrm{O}\right)$ & $\mathrm{IRed}(\mathrm{OH}, \mathrm{OH}, \mathrm{OH})$ & $-53.5 \pm 2.6$ & $-51.9 \pm 2.7$ \\
\hline $\mathrm{IRed}\left(\mathrm{H}_{2} \mathrm{O}, \mathrm{OH}, \mathrm{O}\right)$ & $\operatorname{IRed}\left(\mathrm{OH}, \mathrm{H}_{2} \mathrm{O}, \mathrm{O}\right)$ & $-38.2 \pm 2.3$ & $-39.3 \pm 2.5$ \\
\hline$I \operatorname{Red}\left(\mathrm{H}_{2} \mathrm{O}, \mathrm{OH}\right)$ & $\mathrm{IRed}\left(\mathrm{OH}, \mathrm{H}_{2} \mathrm{O}\right)$ & $112.6 \pm 1.4$ & $115.5 \pm 1.3$ \\
\hline$I \operatorname{Red}\left(\mathrm{H}_{2} \mathrm{O}, \mathrm{O}\right)$ & $\mathrm{IRed}(\mathrm{OH}, \mathrm{OH})$ & $-6.3 \pm 1.8$ & $-15.4 \pm 1.6$ \\
\hline $\operatorname{Red}\left(\mathrm{H}_{2} \mathrm{O}, \mathrm{OH}\right)$ & $\operatorname{Red}\left(\mathrm{OH}, \mathrm{H}_{2} \mathrm{O}\right)$ & $50.7 \pm 1.9$ & $48.2 \pm 1.8$ \\
\hline $\operatorname{Red}\left(\mathrm{H}_{2} \mathrm{O}, \mathrm{O}\right)$ & $\operatorname{Red}(\mathrm{OH}, \mathrm{OH})$ & $-61.0 \pm 2.9$ & $-36.0 \pm 3.0$ \\
\hline $\mathrm{Nl}^{\prime}\left(\mathrm{H}_{2} \mathrm{O}, \mathrm{O}_{2}\right)$ & $\mathrm{NI}\left(\mathrm{H}_{2} \mathrm{O}, \mathrm{O}, \mathrm{O}\right)$ & $22.8 \pm 8.7$ & $25.3 \pm 8.3$ \\
\hline $\mathrm{NI}^{\prime}\left(\mathrm{H}_{2} \mathrm{O}, \mathrm{HO}_{2}\right)$ & $\mathrm{Nl}\left(\mathrm{H}_{2} \mathrm{O}, \mathrm{OH}, \mathrm{O}\right)$ & $-92.3 \pm 9.8$ & $-86.8 \pm 9.4$ \\
\hline $\mathrm{Nl}^{\prime}\left(\mathrm{OH}, \mathrm{HO}_{2}\right)$ & $\mathrm{NI}(\mathrm{OH}, \mathrm{OH}, \mathrm{O})$ & $-117.7 \pm 4.8$ & $-116.4 \pm 4.8$ \\
\hline
\end{tabular}


Table 4. $\mathrm{O}_{2}$ binding free energies and $\mathrm{H}_{2} \mathrm{O}$ dissociation free energies for the various TNC states. The energies were calculated with the QM/MM-PBSA method with surface charges neutralised. An entropy contribution of $30 \mathrm{~kJ} / \mathrm{mol}$ has been added to the dissociated $\mathrm{O}_{2}$ or $\mathrm{H}_{2} \mathrm{O}$ molecule and the energy of the unbound molecule was estimated by a B3LYP/def2-TZVPD calculation in the COSMO continuum solvent with a dielectric constant of 80 (water). The more stable state is marked in bold face, i.e. the reactant state if the energy is positive and the product state otherwise.

\begin{tabular}{|c|c|c|}
\hline \multirow[b]{2}{*}{$\operatorname{Red}\left(\mathrm{H}_{2} \mathrm{O},-\right)+\mathrm{O}_{2} \rightarrow \mathrm{Pl}\left(\mathrm{H}_{2} \mathrm{O}, \mathrm{O}_{2}\right)$} & \multicolumn{2}{|c|}{$\mathrm{Cu}_{\mathrm{T} 1}$ oxidised $\mathrm{Cu}_{\mathrm{T} 1}$ reduced } \\
\hline & 31.3 & 31.3 \\
\hline $\operatorname{Red}(\mathrm{OH},-)+\mathrm{O}_{2} \rightarrow \mathrm{PI}\left(\mathbf{O H}, \mathbf{O}_{2}\right)$ & -44.2 & -38.9 \\
\hline $\mathrm{IOx}\left(\mathrm{H}_{2} \mathrm{O}, \mathrm{H}_{2} \mathrm{O}, \mathrm{OH}\right) \rightarrow \mathrm{IOx}\left(\mathrm{H}_{2} \mathrm{O}, \mathrm{OH}\right)+\mathrm{H}_{2} \mathrm{O}$ & -43.8 & -47.7 \\
\hline $\mathrm{IOx}\left(\mathrm{H}_{2} \mathrm{O}, \mathrm{H}_{2} \mathrm{O}, \mathrm{O}\right) \rightarrow \mathrm{IOx}\left(\mathrm{H}_{2} \mathrm{O}, \mathrm{O}\right)+\mathrm{H}_{2} \mathrm{O}$ & -49.2 & -51.2 \\
\hline $\mathrm{IOx}(\mathrm{OH}, \mathrm{OH})+\mathrm{H}_{2} \mathrm{O}$ & -17.3 & -15.2 \\
\hline $\mathrm{IOx}\left(\mathrm{OH}, \mathrm{H}_{2} \mathrm{O}, \mathrm{O}\right) \rightarrow \mathrm{IOx}(\mathrm{OH}, \mathrm{O})+\mathrm{H}_{2} \mathrm{O}$ & -86.8 & -81.6 \\
\hline$I \operatorname{Red}\left(\mathrm{H}_{2} \mathrm{O}, \mathrm{H}_{2} \mathrm{O}, \mathrm{OH}\right) \rightarrow \operatorname{IRed}\left(\mathrm{H}_{2} \mathrm{O}, \mathrm{OH}\right)+\mathrm{H}_{2} \mathrm{O}$ & -122.6 & -121.0 \\
\hline$I \operatorname{Red}\left(\mathrm{H}_{2} \mathrm{O}, \mathrm{H}_{2} \mathrm{O}, \mathrm{O}\right) \rightarrow \operatorname{IRed}\left(\mathrm{H}_{2} \mathrm{O}, \mathrm{O}\right)+\mathrm{H}_{2} \mathrm{O}$ & -46.8 & -40.5 \\
\hline $\mathrm{IRed}\left(\mathrm{OH}, \mathrm{H}_{2} \mathrm{O}, \mathrm{OH}\right) \rightarrow \operatorname{IRed}(\mathrm{OH}, \mathrm{OH})+\mathrm{H}_{2} \mathrm{O}$ & -10.8 & -11.4 \\
\hline $\mathrm{IRed}\left(\mathrm{OH}, \mathrm{H}_{2} \mathrm{O}, \mathrm{O}\right) \rightarrow \operatorname{IRed}(\mathrm{OH}, \mathrm{O})+\mathrm{H}_{2} \mathrm{O}$ & -98.5 & -97.6 \\
\hline$I \operatorname{Red}\left(\mathrm{H}_{2} \mathrm{O}, \mathrm{H}_{2} \mathrm{O}\right) \rightarrow I \operatorname{Red}\left(\mathrm{H}_{2} \mathrm{O},-\right)+\mathrm{H}_{2} \mathrm{O}$ & -63.3 & -63.6 \\
\hline $\operatorname{Red}\left(\mathrm{H}_{2} \mathrm{O}, \mathrm{H}_{2} \mathrm{O}\right) \rightarrow \operatorname{Red}\left(\mathrm{H}_{2} \mathrm{O},-\right)+\mathrm{H}_{2} \mathrm{O}$ & -5.6 & -4.5 \\
\hline $\operatorname{Red}\left(\mathrm{OH}, \mathrm{H}_{2} \mathrm{O}\right) \rightarrow \operatorname{Red}(\mathrm{OH},-)+\mathrm{H}_{2} \mathrm{O}$ & -8.9 & -10.0 \\
\hline
\end{tabular}


Table 5. Coupled electron-proton transfer reaction energies for the various TNC states $\left(\Delta E_{\mathrm{EPT}}\right)$, obtained from the QTCP energies in Tables 1 and 2. Thus, the electron comes from the $\mathrm{Cu}_{\mathrm{T} 1}$ site and the proton from Asp-373, and the results are give in $p K_{\mathrm{a}}$ units relative to that of an Asp residue $\left(p K_{a} \approx 4\right)$. Consequently, the coupled electron-proton transfer reaction is predicted to be favourable in the forward direction at $\mathrm{pH} 7$ if $\Delta E_{\mathrm{EPT}}$ is larger than 3 and the more stable states have been marked in bold face.

\begin{tabular}{|c|c|}
\hline TNC states & $\Delta E_{\mathrm{EPT}}$ \\
\hline$\overline{\mathrm{PI}\left(\mathrm{H}_{2} \mathrm{O}, \mathrm{O}_{2}\right) \rightarrow \mathrm{NI}^{\prime}\left(\mathrm{H}_{2} \mathrm{O}, \mathrm{HO}_{2}\right)}$ & $-3.9 \pm 0.7$ \\
\hline $\mathrm{PI}\left(\mathrm{OH}, \mathrm{HO}_{2}\right) \rightarrow \mathbf{N I}\left(\mathbf{H}_{\mathbf{2}} \mathbf{O}, \mathrm{HO}_{2}\right)$ & $13.2 \pm 0.8$ \\
\hline $\mathrm{PI}\left(\mathrm{OH}, \mathrm{O}_{2}\right) \rightarrow \mathrm{NI}\left(\mathrm{H}_{2} \mathrm{O}, \mathrm{O}_{2}\right)$ & $1.5 \pm 0.9$ \\
\hline $\mathrm{PI}\left(\mathrm{OH}, \mathrm{O}_{2}\right) \rightarrow \mathrm{NI}\left(\mathrm{OH}, \mathrm{HO}_{2}\right)$ & $0.1 \pm 0.7$ \\
\hline $\mathrm{NI}\left(\mathrm{H}_{2} \mathrm{O}, \mathrm{H}_{2} \mathrm{O}, \mathrm{O}\right) \rightarrow \mathrm{IOx}\left(\mathrm{H}_{2} \mathrm{O}, \mathrm{H}_{2} \mathrm{O}, \mathrm{OH}\right)$ & $2.2 \pm 2.1$ \\
\hline $\mathrm{NI}\left(\mathrm{H}_{2} \mathrm{O}, \mathrm{OH}, \mathrm{O}\right) \rightarrow \mathrm{IOx}\left(\mathrm{H}_{2} \mathrm{O}, \mathrm{H}_{2} \mathrm{O}, \mathrm{O}\right)$ & $-9.0 \pm 2.4$ \\
\hline $\mathrm{NI}\left(\mathrm{H}_{2} \mathrm{O}, \mathrm{O}, \mathrm{O}\right) \rightarrow \mathrm{IOx}\left(\mathrm{H}_{2} \mathrm{O}, \mathrm{OH}, \mathrm{O}\right)$ & $19.3 \pm 0.7$ \\
\hline $\mathrm{NI}(\mathrm{OH}, \mathrm{OH}, \mathrm{O}) \rightarrow \mathrm{IOx}\left(\mathrm{H}_{2} \mathrm{O}, \mathrm{OH}, \mathrm{O}\right)$ & $-10.2 \pm 0.7$ \\
\hline $\mathrm{NI}(\mathrm{OH}, \mathrm{OH}, \mathrm{O}) \rightarrow \mathrm{IOx}\left(\mathrm{OH}, \mathrm{H}_{2} \mathrm{O}, \mathrm{O}\right)$ & $-12.0 \pm 0.7$ \\
\hline $\mathrm{NI}(\mathrm{OH}, \mathrm{OH}, \mathrm{O}) \rightarrow \mathrm{IOx}(\mathrm{OH}, \mathrm{OH}, \mathrm{OH})$ & $-1.4 \pm 0.8$ \\
\hline $\mathrm{IOx}\left(\mathrm{H}_{2} \mathrm{O}, \mathrm{H}_{\mathbf{2}} \mathrm{O}, \mathbf{O}\right) \rightarrow \mathrm{IRed}\left(\mathrm{H}_{2} \mathrm{O}, \mathrm{H}_{2} \mathrm{O}, \mathrm{OH}\right)$ & $-8.5 \pm 0.9$ \\
\hline $\mathrm{IOx}\left(\mathrm{H}_{2} \mathrm{O}, \mathrm{OH}, \mathrm{O}\right) \rightarrow \operatorname{IRed}\left(\mathrm{H}_{2} \mathrm{O}, \mathrm{H}_{2} \mathrm{O}, \mathrm{O}\right)$ & $-1.8 \pm 3.1$ \\
\hline $\mathrm{IOx}\left(\mathrm{H}_{2} \mathrm{O}, \mathrm{O}, \mathrm{O}\right) \rightarrow \operatorname{IRed}\left(\mathrm{H}_{2} \mathrm{O}, \mathrm{OH}, \mathrm{O}\right)$ & $10.0 \pm 0.6$ \\
\hline $\mathrm{IOx}\left(\mathrm{OH}, \mathrm{H}_{2} \mathrm{O}, \mathrm{O}\right) \rightarrow \mathrm{IRed}\left(\mathrm{H}_{2} \mathrm{O}, \mathrm{H}_{2} \mathrm{O}, \mathrm{O}\right)$ & $3.2 \pm 1.5$ \\
\hline $\mathrm{IOx}(\mathrm{OH}, \mathrm{OH}, \mathrm{OH}) \rightarrow \mathrm{IRed}\left(\mathrm{OH}, \mathrm{H}_{2} \mathrm{O}, \mathrm{OH}\right)$ & $7.2 \pm 0.9$ \\
\hline $\mathrm{IOx}(\mathrm{OH}, \mathrm{OH}, \mathrm{O}) \rightarrow \mathrm{IRed}\left(\mathrm{H}_{2} \mathrm{O}, \mathrm{OH}, \mathrm{O}\right)$ & $-12.4 \pm 0.7$ \\
\hline $\mathrm{IOx}(\mathrm{OH}, \mathrm{OH}, \mathrm{O}) \rightarrow \mathrm{IRed}(\mathrm{OH}, \mathrm{OH}, \mathrm{OH})$ & $3.0 \pm 0.8$ \\
\hline $\mathrm{IOx}\left(\mathrm{H}_{2} \mathrm{O}, \mathrm{OH}\right) \rightarrow \mathrm{IRed}\left(\mathrm{H}_{2} \mathrm{O}, \mathrm{H}_{2} \mathrm{O}\right)$ & $-6.8 \pm 0.7$ \\
\hline $\mathrm{IOx}\left(\mathrm{H}_{2} \mathrm{O}, \mathrm{O}\right) \rightarrow \operatorname{IRed}\left(\mathrm{H}_{2} \mathrm{O}, \mathrm{OH}\right)$ & $13.6 \pm 0.7$ \\
\hline $\mathrm{IOx}(\mathrm{OH}, \mathrm{OH}) \rightarrow \operatorname{IRed}\left(\mathrm{H}_{2} \mathrm{O}, \mathrm{OH}\right)$ & $19.1 \pm 0.7$ \\
\hline $\mathrm{IOx}(\mathrm{OH}, \mathrm{O}) \rightarrow \mathrm{IRed}\left(\mathrm{H}_{2} \mathrm{O}, \mathrm{O}\right)$ & $0.7 \pm 0.9$ \\
\hline $\mathrm{IOx}(\mathrm{OH}, \mathrm{O}) \rightarrow \mathrm{IRed}(\mathrm{OH}, \mathrm{OH})$ & $4.2 \pm 0.7$ \\
\hline $\operatorname{IRed}\left(\mathrm{H}_{2} \mathrm{O}, \mathrm{OH}\right) \rightarrow \operatorname{Red}\left(\mathrm{H}_{2} \mathrm{O}, \mathrm{H}_{2} \mathrm{O}\right)$ & $-2.7 \pm 0.7$ \\
\hline$I \operatorname{Red}\left(\mathrm{H}_{2} \mathrm{O}, \mathrm{O}\right) \rightarrow \operatorname{Red}\left(\mathrm{H}_{2} \mathrm{O}, \mathrm{OH}\right)$ & $9.2 \pm 0.8$ \\
\hline $\mathrm{IRed}(\mathrm{OH}, \mathrm{OH}) \rightarrow \operatorname{Red}\left(\mathrm{H}_{2} \mathrm{O}, \mathrm{OH}\right)$ & $7.6 \pm 0.7$ \\
\hline $\mathrm{IRed}(\mathrm{OH}, \mathrm{OH}) \rightarrow \operatorname{Red}\left(\mathrm{OH}, \mathrm{H}_{2} \mathrm{O}\right)$ & $1.8 \pm 0.7$ \\
\hline $\mathrm{IRed}(\mathrm{OH}, \mathrm{O}) \rightarrow \operatorname{Red}\left(\mathrm{H}_{2} \mathrm{O}, \mathrm{O}\right)$ & $27.9 \pm 0.9$ \\
\hline $\mathrm{IRed}(\mathrm{OH}, \mathrm{O}) \rightarrow \operatorname{Red}(\mathrm{OH}, \mathrm{OH})$ & $39.3 \pm 0.7$ \\
\hline$\overline{\mathrm{Ox}}(\mathrm{OH}, \mathrm{OH}) \rightarrow \mathrm{IOx}\left(\mathrm{H}_{2} \mathrm{O}, \mathrm{OH}\right)$ & $19.3 \pm 0.7$ \\
\hline
\end{tabular}


Figure 1. The consensus reaction scheme of the MCOs, considering only the oxidation state of the TNC. ${ }^{1,10,13}$

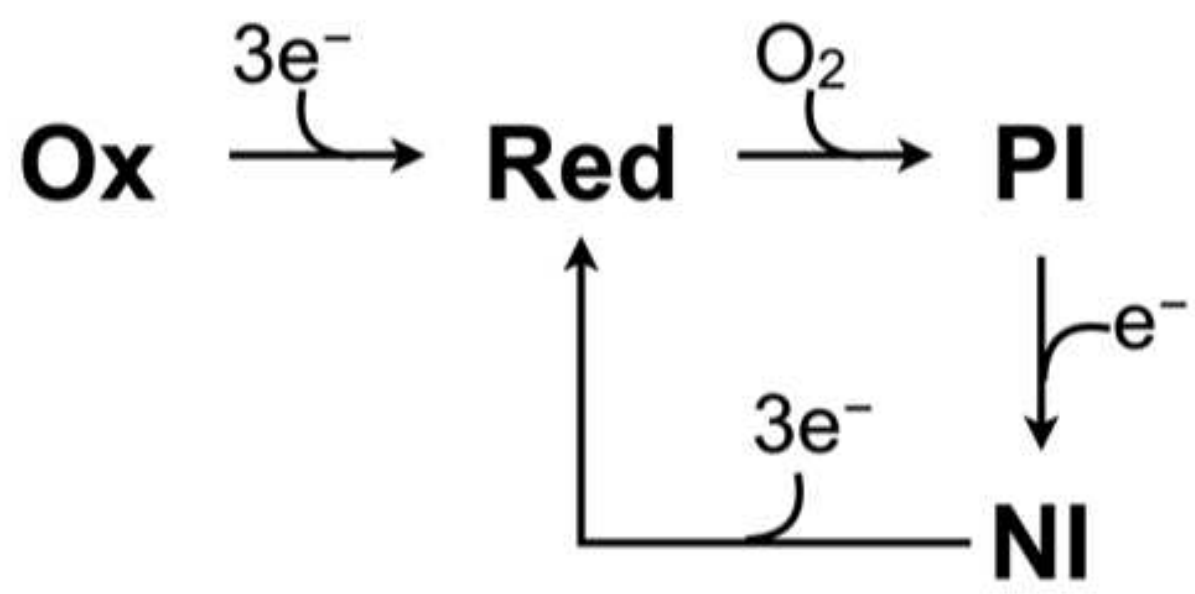

21

22

23

24

25

26

27

28

29

30

31

32

33

34

35

36

37

38

39

40

41

42

43

44

45

46

47

48

49

50

51

52

53

54

55

56

57

58

59

60 
Figure 2. Schematic picture of the various perturbations performed for the electron- and protontransfer reactions. In the former case the two letters for each system represent the charges and the coordinates, respectively, which may be either those for the starting state $(A$, in which the TNC is oxidised and $\mathrm{Cu}_{\mathrm{T} 1}$ is reduced) or the final state $(\mathrm{B}$, in which the TNC is reduced and $\mathrm{Cu}_{\mathrm{T} 1}$ is oxidised). For the proton-transfer reaction, the four letters represent the proton on the TNC site, charges, the coordinates, and the proton on Asp-373. The proton can be either modelled as a full proton, with zeroed dummy parameters (D), or be deleted $(\varnothing)$. The charges and coordinates can be either those of the starting state (A, in which the TNC is protonated and Asp-373 is deprotonated) or the final state (B, in which the TNC is deprotonated and Asp-373 is protonated). The label for each free energy and the number of perturbation steps are also indicated.

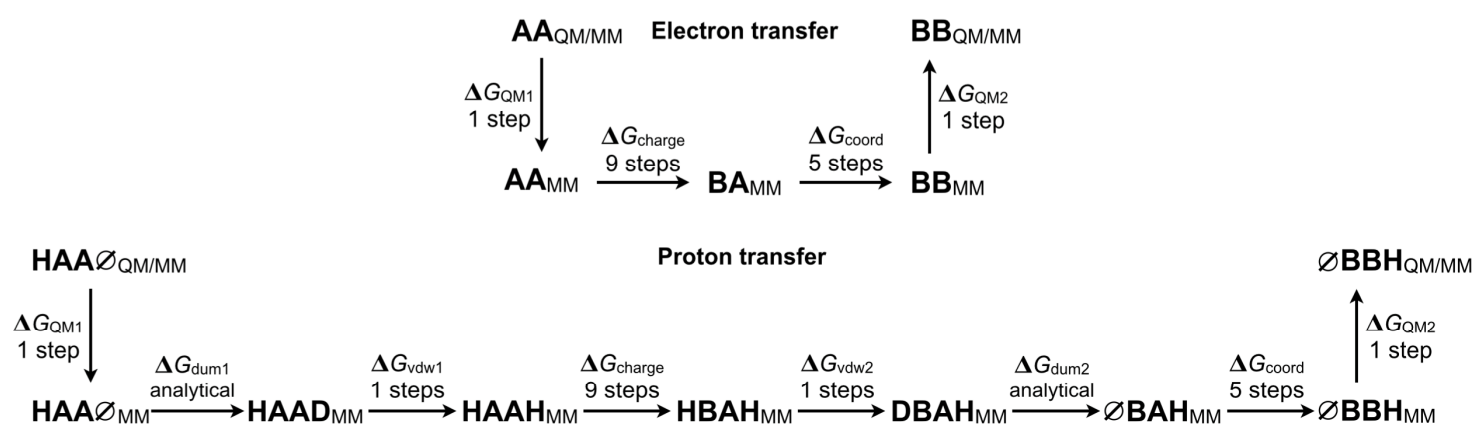


Figure 3. Structures of the $\mathrm{QM}$ systems for a) the $\mathrm{Cu}_{\mathrm{T} 1}$ site and for the TNC in the b) $\mathrm{Ox}(\mathrm{OH}, \mathrm{OH})$, c) $\operatorname{Red}(\mathrm{OH})$, d) $\mathrm{Pl}\left(\mathrm{OH}, \mathrm{O}_{2}\right)$, and e) $\mathrm{NI}(\mathrm{OH}, \mathrm{OH}, \mathrm{O})$ states. $\mathrm{Cu}$ ions are orange, $\mathrm{S}$ atoms yellow, $\mathrm{C}$ atoms grey, $\mathrm{N}$ atoms blue, $\mathrm{O}$ atoms red, and $\mathrm{H}$ atoms white.

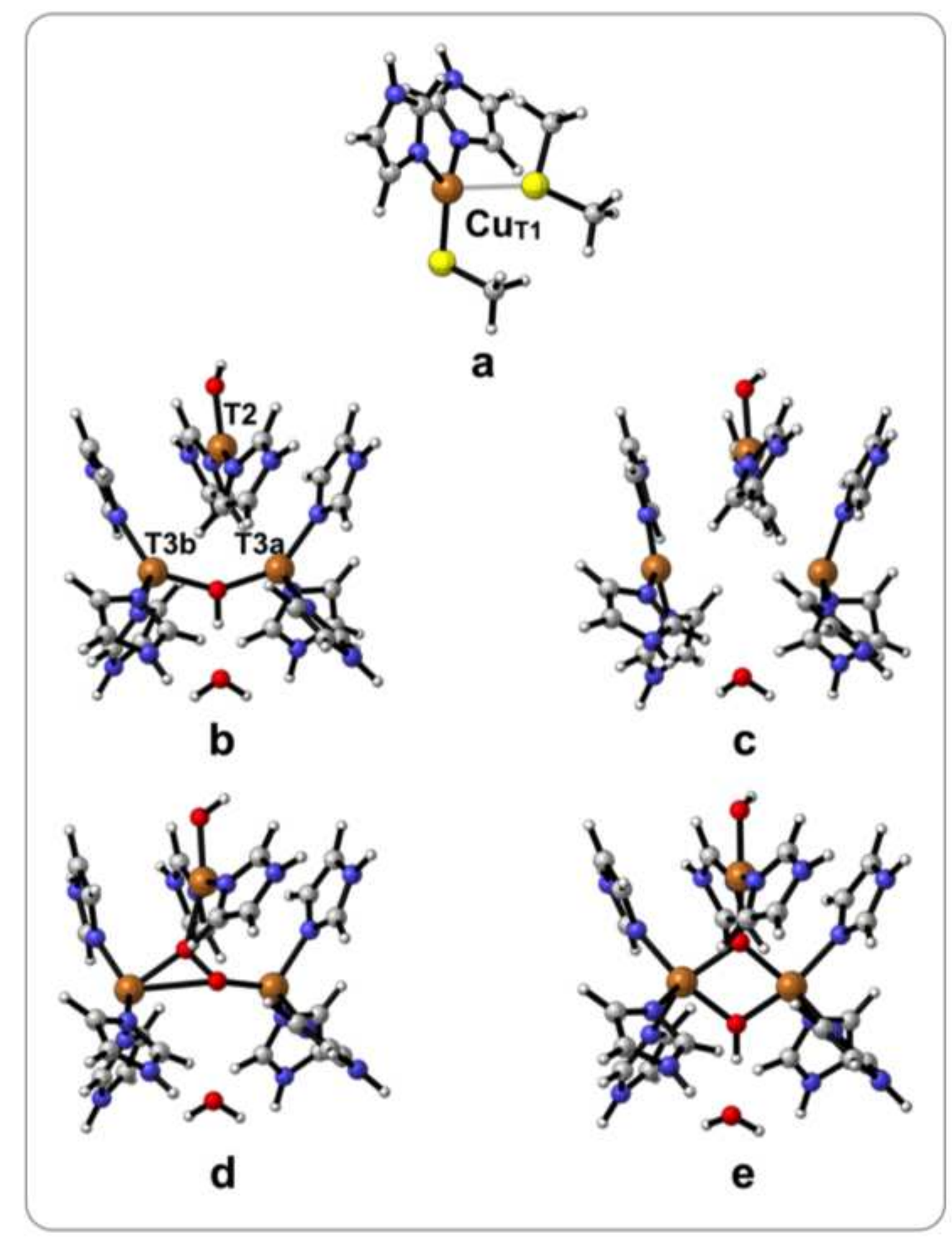


Figure 4. Dependence of the estimated redox potential of the $\mathrm{Cu}_{\mathrm{T} 1}$ site on the state and charge of the TNC, colour-coded after the charge of the TNC. The results are based on the QM/MM-GBSA results (which give the smallest influence on the redox potentials among methods used) for the proteins with neutralised charges, sorted after the net charge (legend) and oxidation state of the TNC site.

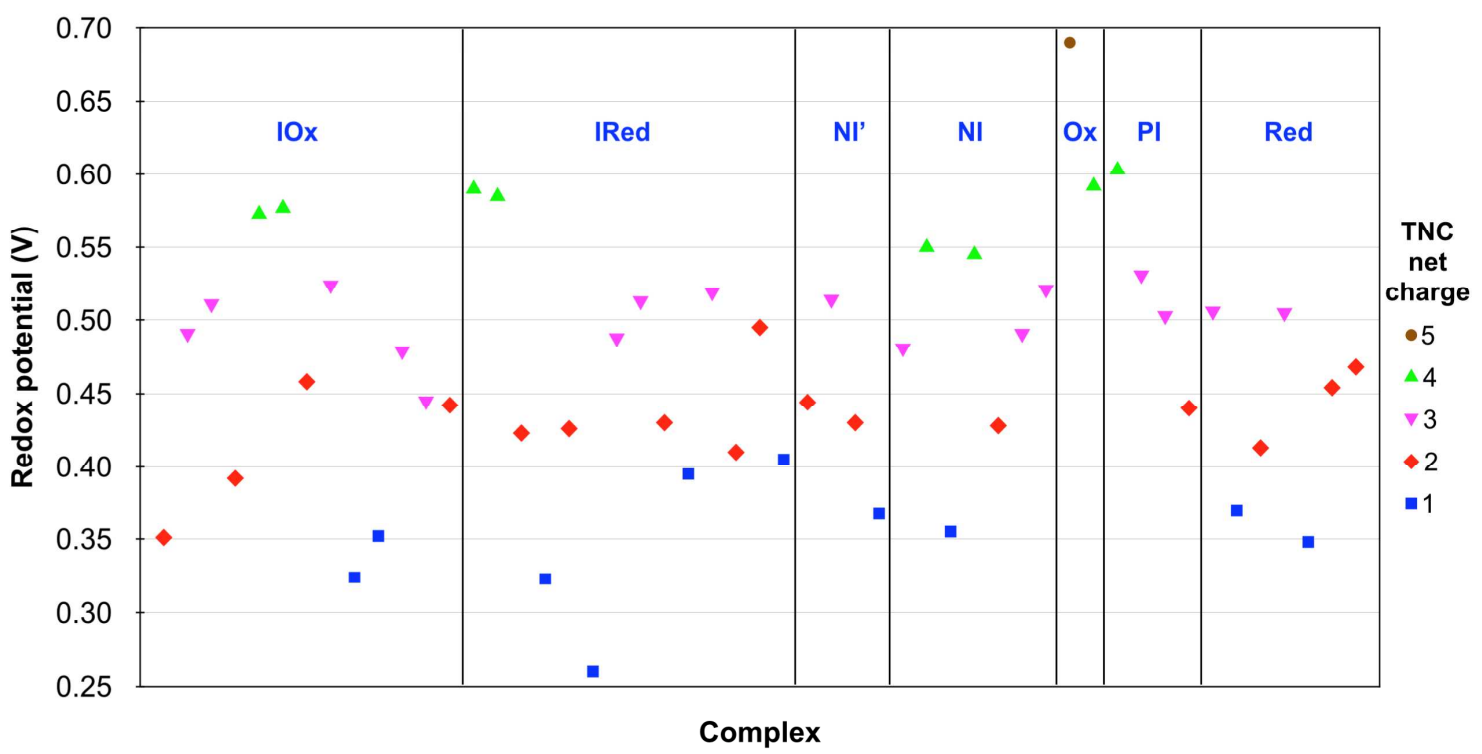


Figure 5. The suggested catalytic cycle of the MCOs. Calculated reaction free energies (in $\mathrm{kJ} / \mathrm{mol}$ from Tables 3-5) are given for each step, assuming a $\mathrm{pH}$ of 7 , that the electrons come from the $\mathrm{Cu}_{\mathrm{T} 1}$ site, and that the $\mathrm{Cu}_{\mathrm{T} 1}$ site is reduced in the steps not involving electron transfer.

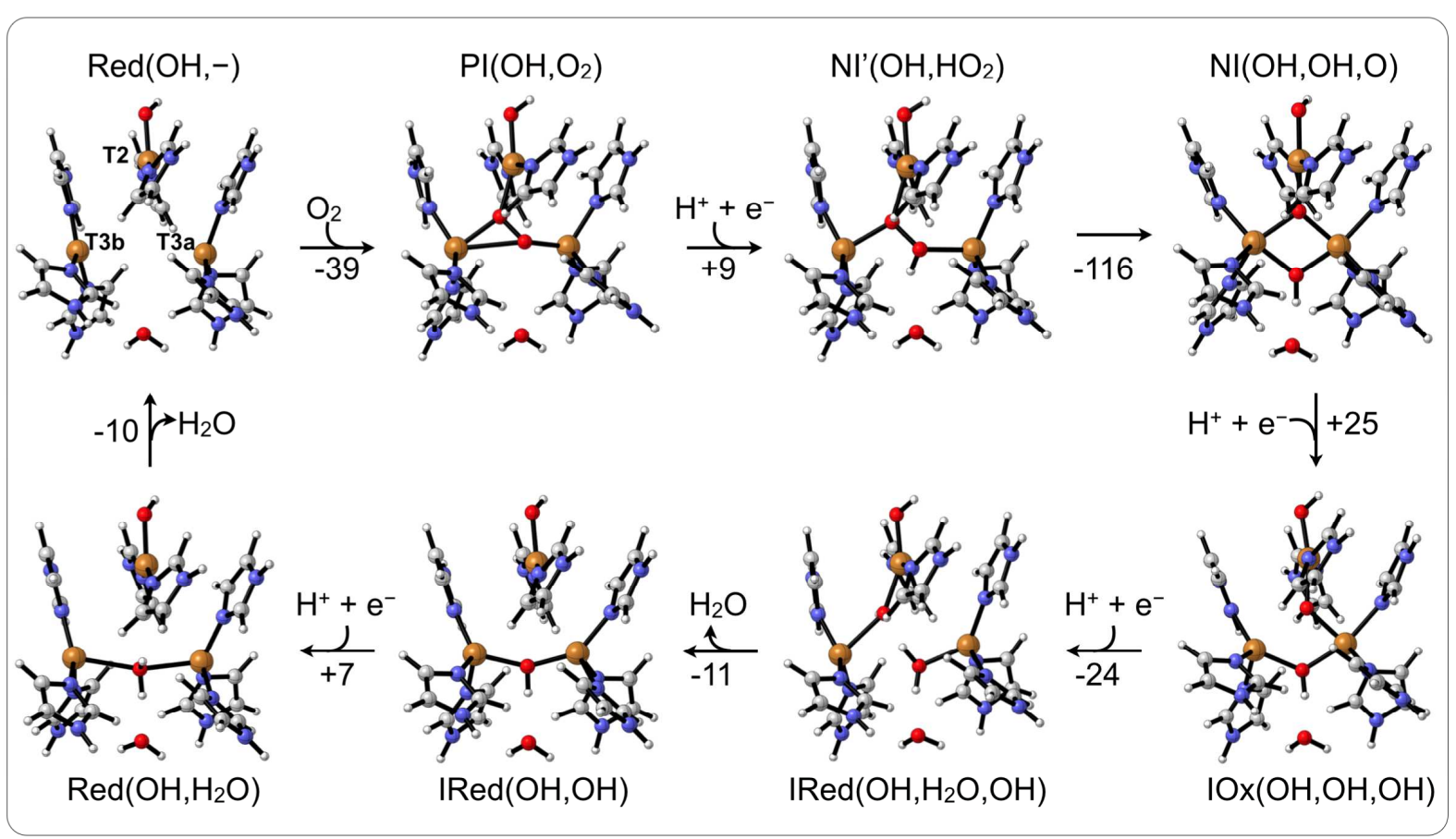




\section{TOC graphics}

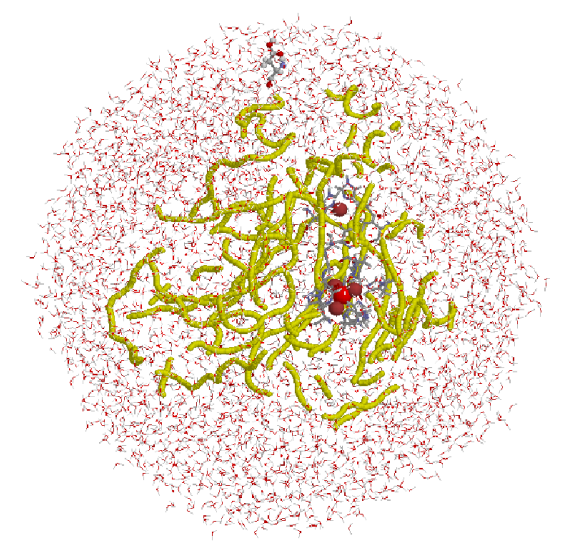

